PNNL-16415

WMP-31815

Rev. 0

Pacific Northwest

National Laboratory

Operated by Battelle for the

U.S. Department of Energy

\title{
Borehole Summary Report for C4997 Rotary Drilling, WTP Seismic Boreholes Project, CY 2006
}

T. J. DiFebbo

February 2007

Prepared by Environmental Quality Management, Inc. and Fluor Hanford, Inc.

for the Pacific Northwest National Laboratory under Contract DE-AC05-76RL01830

with the U.S. Department of Energy 


\title{
DISCLAIMER
}

This report was prepared as an account of work sponsored by an agency of the United States Government. Neither the United States Government nor any agency thereof, nor Battelle Memorial Institute, nor any of their employees, makes any warranty, express or implied, or assumes any legal liability or responsibility for the accuracy, completeness, or usefulness of any information, apparatus, product, or process disclosed, or represents that its use would not infringe privately owned rights. Reference herein to any specific commercial product, process, or service by trade name, trademark, manufacturer, or otherwise does not necessarily constitute or imply its endorsement, recommendation, or favoring by the United States Government or any agency thereof, or Battelle Memorial Institute. The views and opinions of authors expressed herein do not necessarily state or reflect those of the United States Government or any agency thereof.

\author{
PACIFIC NORTHWEST NATIONAL LABORATORY \\ operated by \\ BATTELLE \\ for the \\ UNITED STATES DEPARTMENT OF ENERGY \\ under Contract DE-AC05-76RL01830
}

Printed in the United States of America
Available to DOE and DOE contractors from the
Office of Scientific and Technical Information,
P.O. Box 62, Oak Ridge, TN 37831-0062;
ph: (865) 576-8401
fax: (865) 576-5728
email: reports@adonis.osti.gov

\author{
Available to the public from the National Technical Information Service, \\ U.S. Department of Commerce, 5285 Port Royal Rd., Springfield, VA 22161 \\ ph: (800) 553-6847 \\ fax: (703) 605-6900 \\ email: orders@ntis.fedworld.gov \\ online ordering: http://www.ntis.gov/ordering.htm
}

This document was printed on recycled paper. 
WMP-31815

Revision 0

REISSUE

\section{Borehole Summary Report for C4997 Rotary Drilling, WTP Seismic Boreholes Project, CY 2006}

Prepared for the U.S. Department of Energy

Assistant Secretary for Environmental Management

Project Hanford Management Contractor for the

U.S. Department of Energy under Contract DE-AC06-96RL13200

\section{$=1001$}

P.O. Box 1000

Richland, Washington 


\section{Borehole Summary Report for C4997 Rotary Drilling, WTP Seismic Boreholes Project, CY 2006}

Document Type: TR

Program/Project: WM

Date Published

February 2007

Prepared for the U.S. Department of Energy

Assistant Secretary for Environmental Management

Project Hanford Management Contractor for the

U.S. Department of Energy under Contract DE-AC06-96RL13200

\section{FLUOR。}

P.O. Box 1000

Richland, Washington 
WMP-31815

Revision 0

TRADEMARK DISCLAIMER

Reference herein to any specific commercial product, process, or service by trade name, trademark, manufacturer, or otherwise, does not necessarily constitute or imply its endorsement, recommendation, or favoring by the United

States Government or any agency thereof or its contractors or subcontractors.

This report has been reproduced from the best available copy.

Printed in the United States of America 
WMP-31815, Rev. 0

\section{APPROVAL PAGE}

Title:

Borehole Summary Report for C4997 Rotary Drilling, WTP Seismic Boreholes Project, CY 2006

Approvals:

J. V. Borghese

Manager, Remedial Actions, Groundwater Remediation Project
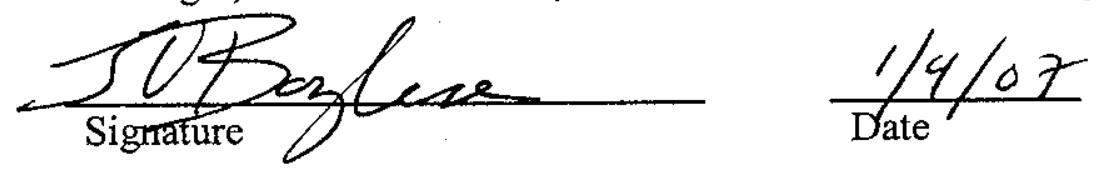

L. C. Swanson

Manager, Geosciences, Groundwater Remediation Project

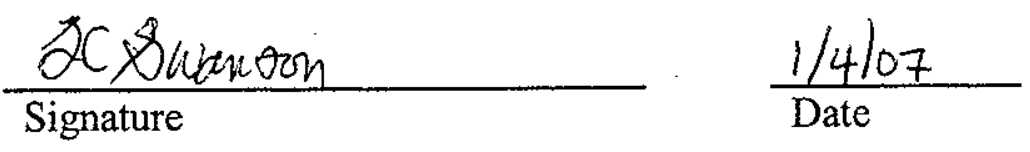

J. A. Winterhalder

Environmental Compliance Officer, Groundwater Remediation Project

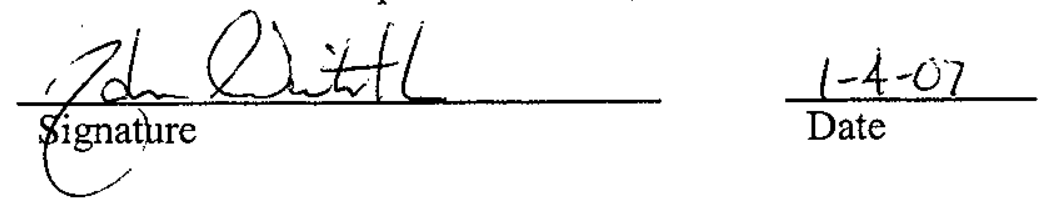

C. S. Wright

Task Lead, Groundwater Remediation Project
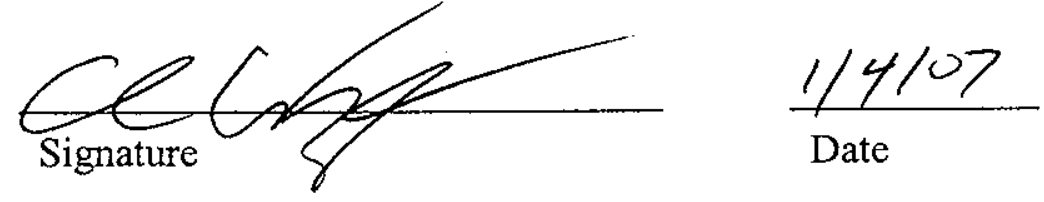
WMP-31815, Rev. 0

This page intentionally left blank. 


\section{TABLE OF CONTENTS}

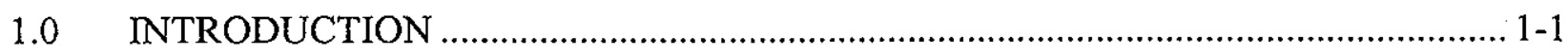

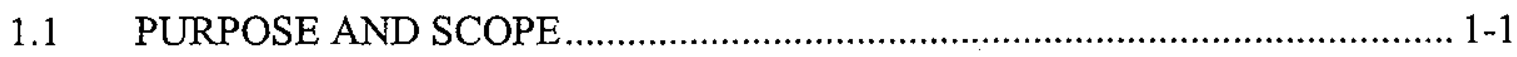

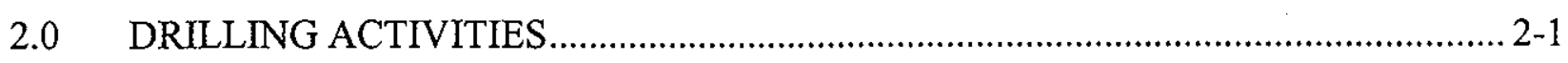

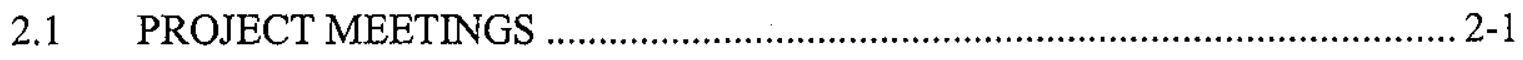

2.2 DRILLING SUMMARY ...................................................................... 2-1

2.3 BASALT AND INTERBED SEDIMENT SAMPLING ………......................... 2-2

2.4 BOREHOLE GEOPHYSICAL LOGGING ……............................................

2.5 RADIOLOGICAL FIELD SCREENING ................................................ 2-2

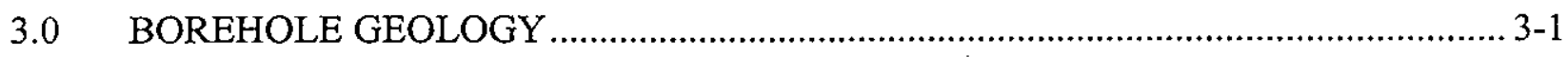

3.1 OVERBURDEN SEDIMENT DRILLING ....................................................... 3-1

3.2 BASALT AND INTERBED SEDIMENT DRILLING ..................................... 3-1

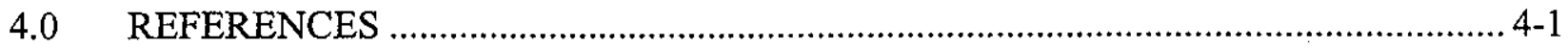

\section{FIGURES}

Figure 1-1. Waste Treatment Plant at Hanford, Washington.

Figure 2-1. Planned Drilling Locations at the Waste Treatment Plant, Hanford, Washington.

\section{APPENDICES}

APPENDIX A. PHOTOCOPIED Geologic Borehole Logs for Saddle Mountains Basalt formation and upper wanapum basalt formation in borehole c4997 ...................A-i APPENDIX B. Photocopied geologic borehole logs for hanford and ringold formations

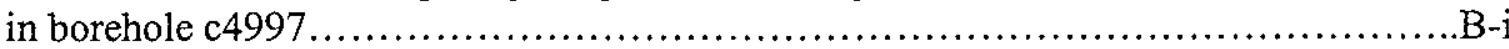


WMP-31815, Rev. 0

This page intentionally left blank. 


\section{WMP-31815, Rev. 0}

\section{ACRONYMS}

bgs

DNFSB

FH

PNNL

SAP

TD

USACE

WTP

EQM

DOE below ground surface

Defense Nuclear Facilities Safety Board

Fluor Hanford, Inc.

Pacific Northwest National Laboratory

Sampling and Analysis Plan

total depth

U.S. Army Corps of Engineers

Waste Treatment Plant

Environmental Quality Management

Department of Energy 
WMP-31815, Rev. 0

This page intentionally left blank. 


\section{METRIC CONVERSION CHART}

\begin{tabular}{|c|c|c|c|c|c|}
\hline \multicolumn{3}{|l|}{ Into Metric Units } & \multicolumn{3}{|c|}{ Out of Metric Units } \\
\hline If You Know & Multiply By & To Get & If You Know & Multiply By & To Get \\
\hline Length & & & Length & & $\cdot$ \\
\hline inches & 25.4 & millimeters & millimeters & 0.039 & inches \\
\hline inches & 2.54 & Centimeters & centimeters & 0.394 & inches \\
\hline feet & 0.305 & Meters & meters & 3.281 & feet \\
\hline yards & 0.914 & Meters & meters & 1.094 & yards \\
\hline miles & 1.609 & Kilometers & kilometers & 0.621 & miles \\
\hline Area & & & Area & & \\
\hline sq. inches & 6.452 & sq. centimeters & sq. centimeters & 0.155 & sq. inches \\
\hline sq. feet & 0.093 & sq. meters & sq. meters & 10.76 & sq. feet \\
\hline sq. yards & 0.0836 & sq. meters & sq. meters & 1.196 & sq. yards \\
\hline sq. miles & 2.6 & sq. kilometers & sq. kilometers & 0.4 & sq. miles \\
\hline Acres & 0.405 & Hectares & hectares & 2.47 & acres \\
\hline Mass (weight) & & & Mass (weight) & & \\
\hline Ounces & 28.35 & Grams & grams & 0.035 & ounces \\
\hline Pounds & 0.454 & Kilograms & kilograms & 2.205 & pounds \\
\hline Ton & 0.907 & metric ton & metric ton & 1.102 & ton \\
\hline Volume & & & Volume & & \\
\hline Teaspoons & 5 & Milliliters & milliliters & 0.033 & fluid ounces \\
\hline Tablespoons & 15 & Milliliters & liters & 2.1 & pints \\
\hline fluid ounces & 30 & Milliliters & liters & 1.057 & quarts \\
\hline Cups & 0.24 & Liters & liters & 0.264 & gallons \\
\hline Pints & 0.47 & Liters & cubic meters & 35.315 & cubic feet \\
\hline Quarts & 0.95 & Liters & cubic meters & 1.308 & cubic yards \\
\hline Gallons & 3.8 & Liters & & & \\
\hline cubic feet & 0.028 & cubic meters & & & \\
\hline cubic yards & 0.765 & cubic meters & & & \\
\hline Temperature & & & Temperature & & \\
\hline Fahrenheit & $\begin{array}{l}\text { subtract } 32 \text {, } \\
\text { then } \\
\text { multiply by } \\
5 / 9\end{array}$ & Celsius & Celsius & $\begin{array}{l}\text { multiply by } \\
9 / 5, \text { then add } \\
32\end{array}$ & Fahrenheit \\
\hline Radioactivity & & & Radioactivity & & \\
\hline Picocuries & 37 & Millibecquerel & millibecquerel & 0.027 & picocuries \\
\hline
\end{tabular}


WMP-31815, Rev. 0

This page intentionally left blank. 


\subsection{INTRODUCTION}

The following Final Geologic Borehole Report briefly describes the drilling of a single borehole at the Waste Treatment Plant (WTP) on the Hanford, Washington, U.S. Department of Energy (DOE) reservation. The location of the WTP is illustrated in Figure 1-1. The borehole was designated as "C4997", and was drilled to obtain seismic and lithologic data for the Pretreatment Facility and High-Level Waste Vitrification Plant in the WTP. Borehole C4997 was drilled and logged to a total depth of $1428 \mathrm{ft}$ below ground surface (bgs) on October 8, 2006, and was located approximately $150 \mathrm{ft}$ from a recently cored borehole, designated as "C4998". Pacific Northwest National Laboratory (PNNL) determined the locations for C4997, C4998, and other boreholes at the WTP in cooperation with the U.S. Army Corps of Engineers (USACE) Review Panel, and the Defense Nuclear Facilities Safety Board (DNFSB). The total depth of Borehole C4997 was also determined by PNNL.

The documents listed below were provided by Fluor Hanford (FH) and PNNL for conducting drilling activities and preparing this report. Additional supporting documents are referenced in those shown below. The information presented in this report is primarily based on the Sampling and Analysis Plan (SAP) listed below, and the geologic borehole logs in Appendices A and B.

- Sampling and Analysis Plan, Waste Treatment Plant, Seismic Borehole Project (PNNL-15848, Rev. 2)

- Health and Safety Plan for the WTP Seismic Borehole Project (Duratek Federal Services, Inc. for PNNL, Rev. 1).

- Drilling Plan for the Waste Treatment Plant Seismic Test Borehole Project; Gardner MG, KD Reynolds, and DE Skoglie; 2006; Duratek Federal Services, Richland, Washington (FS-RW-SWS-PN-005, Rev. 0)

- Geologic Logging; Groundwater Remediation Project Administrative Procedure, Fluor Hanford, Inc., Richland, Washington (GRP-EE-01-7.0, Rev. 1)

FH contracted with Environmental Quality Management, Inc. (EQM) to provide specific geologic services for the portion of Borehole C4997 that was drilled into basalt and interbed sediments underlying the Hanford and Ringold Formations. Personnel from an EQM subcontractor, Landau Associates (Landau), prepared geologic borehole logs, documented field activities, and collected grab samples from drill cuttings. The drilling contractors for Borehole $\mathrm{C} 4997$ were provided by FH and PNNL, and were not directed by EQM or Landau. Geophysical data were obtained from the borehole at various depth intervals by other $\mathrm{FH}$ and PNNL contractors.

\subsection{PURPOSE AND SCOPE}

As requested by $\mathrm{FH}$, the primary purpose of this document is to convey geologic borehole logs to FH and PNNL for the basalt and interbed sediments in Borehole C4997. The original signed geologic borehole logs for the Saddle Mountains Basalt Formation and upper Wanapum Basalt Formation were provided to FH on November 13, 2006. 
Photocopies of the geologic borehole logs are included in Appendix A. The basalt and interbed sediment borehole logs were prepared on-site during drilling operations.

Borehole logs for the overlying Hanford and Ringold Formations in Borehole C4997 were prepared by another contractor; photocopies were provided by $\mathrm{FH}$, and are attached in Appendix B.

Drilling activities are documented by Landau on "Field Activity Reports - Daily Drilling" (daily activity reports). The daily activity reports can be viewed in the Hanford Well Information System (HWIS) Interface web page. FH provided both the geologic borehole log and daily activity report forms. Geophysical and other data from Borehole C4997 are not included in this report. 
WMP-31815, Rev. 0

Figure 1-1. Waste Treatment Plant at Hanford, Washington.

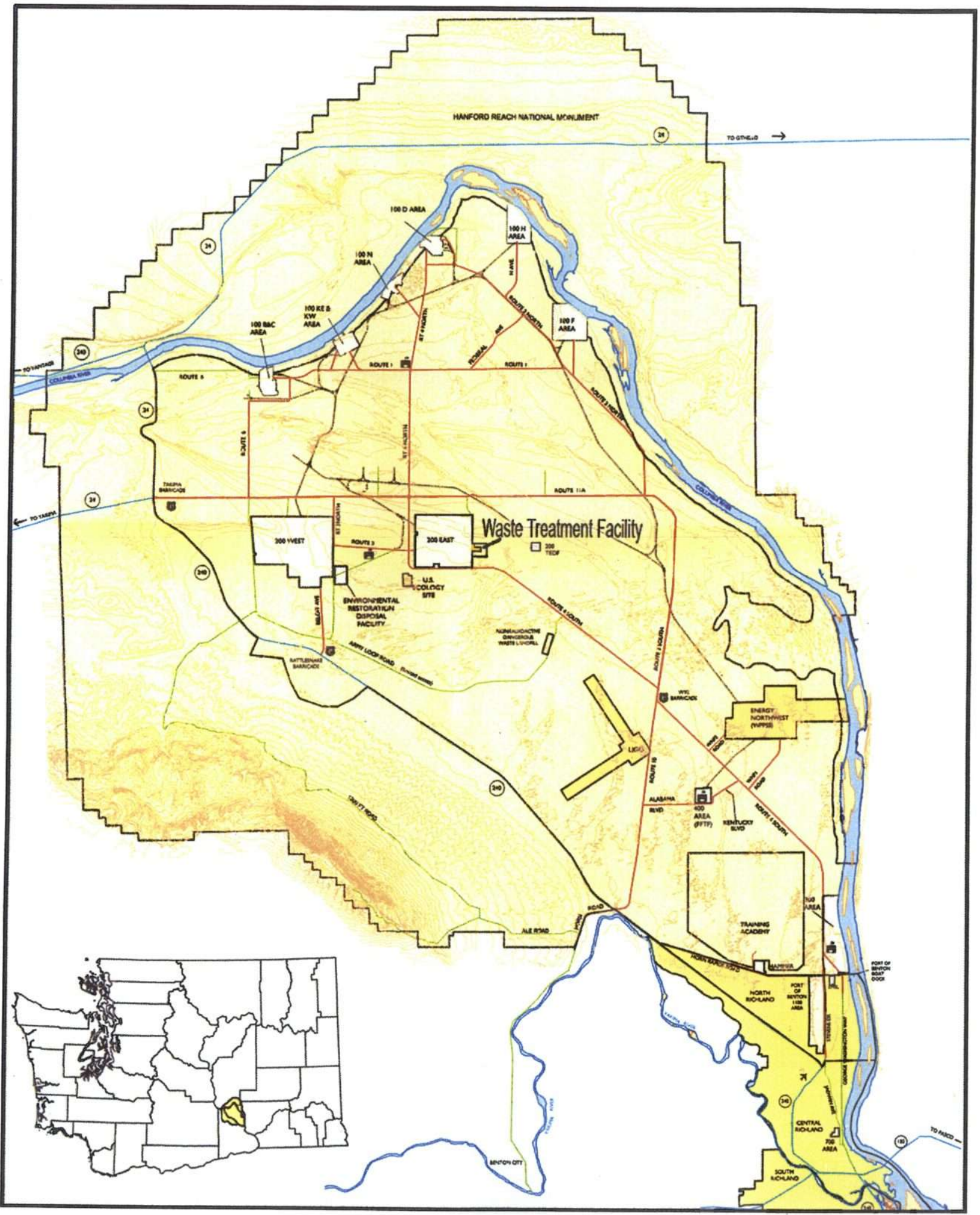


WMP-31815, Rev. 0

This page intentionally left blank. 


\subsection{DRILLING ACTIVITIES}

The Sampling and Analysis Plan, Waste Treatment Plant, Seismic Borehole Project (SAP) listed the four objectives shown below for drilling Borehole C4997 and other boreholes at the WTP.

- Identify geologic units below the WTP,

- Characterize sediments and basalt below the WTP,

- Provide core samples for dynamic laboratory testing, and

- Obtain shear wave, compressional wave, and other geophysical data.

The geologic logging and grab sampling conducted by Landau personnel was directed toward accomplishing the first two objectives for identifying and characterizing the basalt and interbed sediments of the Saddle Mountains Basalt Formation and the upper Wanapum Basalt Formation. The two objectives for obtaining core samples and geophysical data were the responsibility of other PNNL and FH contractors.

As shown on the map in Figure 2-1, Borehole C4997 was drilled near the Pretreatment Facility and High-Level Waste Vitrification Plant of the WTP. Borehole C4998 was drilled approximately $150 \mathrm{ft}$ from C4997. The basalt and interbed sediments in Borehole C4998 were cored. Coring operations at C4998 were in progress when mud rotary drilling of the Elephant Mountain Member basalt began in Borehole C4997.

\subsection{PROJECT MEETINGS}

An initial project meeting for drilling the basalt and interbed sediments in Borehole C4997 was held on August 15, 2006 at EQM's office in Richland, Washington. PNNL and FH representatives described the general project scope of work, expected lithologies, and sampling plans to on-site geologists.

Daily meetings. site procedures, drilling operations, and security plans were discussed at an on-site project pre-job and safety meeting on August 21, 2006. EQM and Landau personnel were informed in the kickoff meeting that the "entry borehole" for C4997 was completed. Excavation permit requirements, end-of-shift forms, and other site procedures were discussed at an on-site quality assurance meeting on August 22, 2006.

\subsection{DRILLING SUMMARY}

A cable-tool rig began drilling the C4997 "entry borehole" on July 30, 2006, and ended on August 18, 2006 at a depth of $401 \mathrm{ft}$ bgs. The "entry borehole" was drilled through the Hanford and Ringold Formations to a depth of $383 \mathrm{ft}$ bgs where the top of basalt was encountered. The "entry borehole" was then drilled an additional $18 \mathrm{ft}$ into the Elephant Mountain Member of the Saddle Mountains Basalt Formation.

Drilling continued on the $\mathrm{C} 4997$ borehole with a mud rotary rig on August 22, 2006 to a total depth of $1,428 \mathrm{ft}$ bgs on October 8, 2006. Landau personnel prepared geologic borehole logs of the basalt and interbed sediments of the Saddle Mountains and upper 
Wanapum Basalt Formations to a total depth of $1,428 \mathrm{ft}$ bgs. Borehole C4997 was inadvertently deepened to $1,435.7 \mathrm{ft}$ bgs on October 12,2006 when the driller was attempting to drill-out cement at the bottom of the borehole. The driller error is noted on the October 12, 2006 Daily Field Report from Martin Gardner, Energy Solutions, and Thomas M. Brouns, WTP Seismic Boreholes Project Manager for PNNL. An emailed copy of the Daily Field Report is attached in Appendix D.

\subsection{BASALT AND INTERBED SEDIMENT SAMPLING}

Grab samples of basalt and interbed sediments were collected at a depth interval of five feet when sufficient drill cuttings were retrieved. PNNL provided glass pint jars, chip trays, and sand sample bags for the grab samples, and retained the samples that were collected by Landau. As directed by PNNL, a portion of each drill cutting sample was "washed", placed in a sand bag, and labeled. Drilling mud was washed from samples by placing them in a sieve and passing water over them. The unwashed portion of each sample was placed in a chip tray and a pint jar, and then labeled.

On September 12, 2006, PNNL requested on-site geologists to collect a larger quantity of washed samples from the upper $30 \mathrm{ft}$, middle, and lower $30 \mathrm{ft}$ of each basalt member. As a result, additional sample quantities were collected from depths of $980,1030,1080$, 1235,1305 , and $1370 \mathrm{ft}$ bgs.

\subsection{BOREHOLE GEOPHYSICAL LOGGING}

As described in the SAP, one of the primary reasons for drilling C4997 and other boreholes at the WTP was the acquisition of shear wave, compressional wave, and other geophysical data. The SAP describes planned geophysical logging activities by Bruce Redpath of Redpath Geophysics and Dr. Kenneth Stokoe, II from the University of Texas-Austin. Drilling and geological logging were periodically suspended to allow for various downhole logging activities. Neither EQM nor Landau were responsible for any of the downhole logging operations.

\subsection{RADIOLOGICAL FIELD SCREENING}

Radiological control technicians surveyed radiation levels during drilling operations. The technicians informed on-site personnel that no ionizing radiation was detected above background levels at Borehole C4997. 
WMP-31815, Rev. 0

Figure 2-1. Planned Drilling Locations at the Waste Treatment Plant, Hanford, Washington.

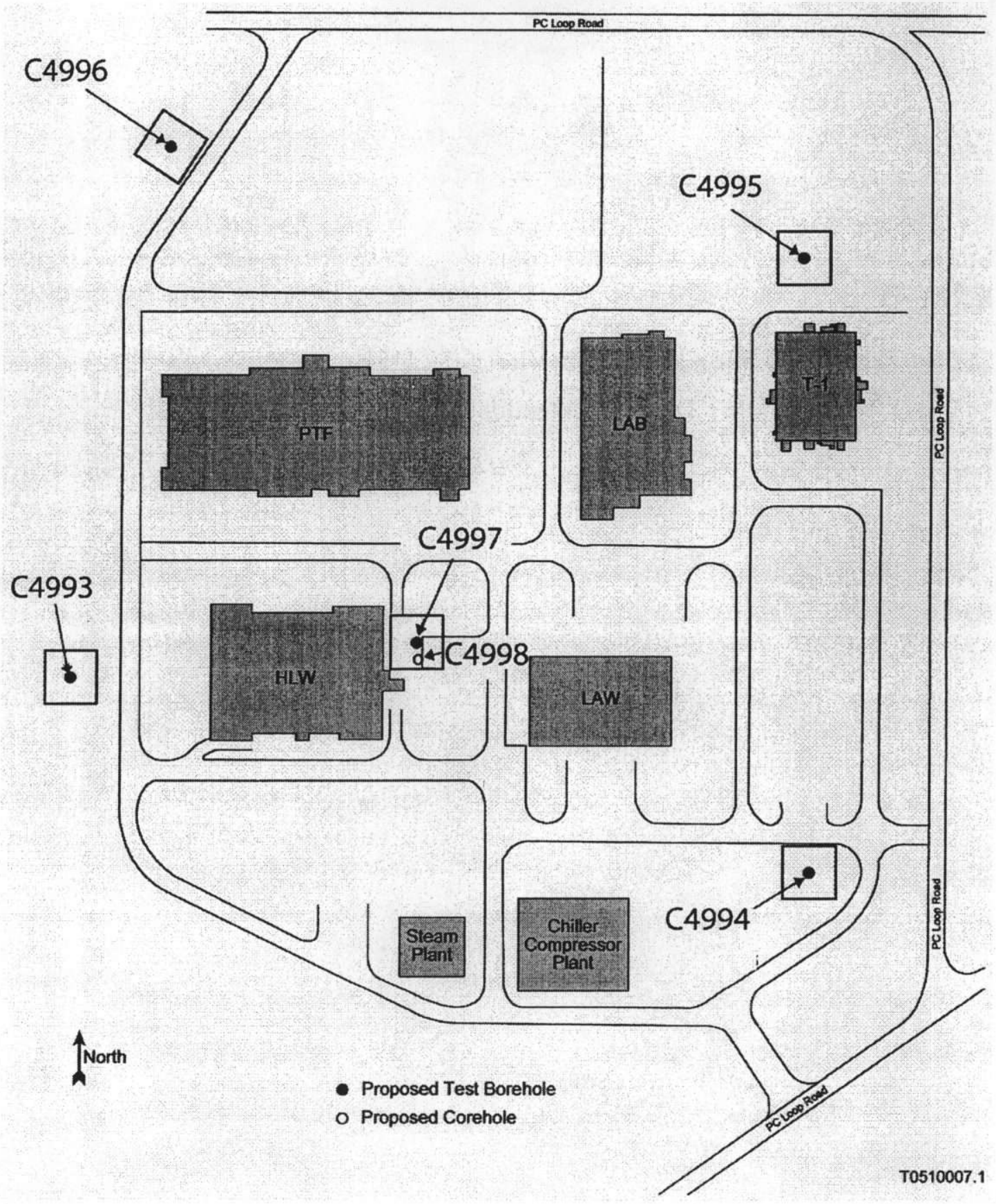


WMP-31815, Rev. 0

This page intentionally left blank. 
WMP-31815, Rev. 0

\subsection{BOREHOLE GEOLOGY}

Borehole C4997 was drilled through the Hanford and Ringold Formations overburden, and the Saddle Mountains Basalt Formation, into the Priest Rapids Member of the upper Wanapum Basalt Formation. The total depth of $\mathrm{C} 4997$ was 1,428 $\mathrm{ft}$ bgs when geologic logging was completed on October 8, 2006. As explained below, the driller deepened the borehole to $1,435.7 \mathrm{ft}$ bgs on October 12, 2006.

\subsection{OVERBURDEN SEDIMENT DRILLING}

The overburden sediments in Borehole C4997 consisted of the silt, sand, and gravel of the Hanford and Ringold Formations. An entry borehole was drilled with a cable tool rig through the overburden sediments, and then extended $18 \mathrm{ft}$ into the uppermost basalt to a final depth of approximately $401 \mathrm{ft}$ bgs. The top of the Elephant Mountain Member basalt was encountered at a depth of approximately $383 \mathrm{ft}$ bgs. The geologic logs for the entry borehole are attached in Appendix B.

"Drill cutting returns" to ground surface were enhanced by adding potable water to the entry borehole. It was impossible to identify when groundwater was initially encountered due to the addition of water to the entry borehole. The geologic borehole logs in Appendix B indicate that groundwater samples were collected at depth intervals of 279.5 to $280.4 \mathrm{ft}, 303 \mathrm{ft}$, and 364.5 to $367.6 \mathrm{ft}$ bgs. The geologic borehole logs also indicate that split-spoon samples were collected for dynamic testing.

\subsection{BASALT AND INTERBED SEDIMENT DRILLING}

The top of the uppermost basalt, Elephant Mountain Member, was encountered in the entry borehole at a depth of $383 \mathrm{ft}$ bgs. The top of the lithologic units listed below were identified at the indicated depths on the geologic borehole logs in Appendix A.

Saddle Mountains Basalt Formation

- Elephant Mountain Member basalt $383 \mathrm{ft}$ bgs

- Rattlesnake Ridge Interbed $495 \mathrm{ft}$ bgs

- Pomona Member basalt $537 \mathrm{ft}$ bgs

- Selah Interbed $737 \mathrm{ft}$ bgs

- Esquatzel Member basalt $\quad 760.5 \mathrm{ft}$ bgs

- Cold Creek Interbed $855.5 \mathrm{ft}$ bgs

- Umatilla Member basalt $\quad 950.4 \mathrm{ft}$ bgs

- Mabton Interbed $1109 \mathrm{ft}$ bgs

Wanapum Basalt Group

- Priest Rapids Member basalt $1205.5 \mathrm{ft}$ bgs 
WMP-31815, Rev. 0

This page intentionally left blank. 
WMP-31815, Rev. 0

\subsection{REFERENCES}

Sampling and Analysis Plan, Waste Treatment Plant, Seismic Borehole Project (PNNL15848, Rev. 2)

Health and Safety Plan for the WTP Seismic Borehole Project (Duratek Federal Services, Inc., Rev. 1).

Drilling Plan for the Waste Treatment Plant Seismic Test Borehole Project; Gardner MG, KD Reynolds, and DE Skoglie; 2006; Duratek Federal Services, Richland, Washington (FS-RW-SWS-PN-005, Rev. 0)

Geologic Logging; Groundwater Remediation Project Administrative Procedure, Fluor Hanford, Inc., Richland, Washington (GRP-EE-01-7.0, Rev. 1) 
WMP-31815, Rev. 0

This page intentionally left blank. 
WMP-31815, Rev. 0

APPENDIX A

PHOTOCOPIED Geological Borhole Logs for Saddle Moutains Basalt formation and Upper wanapum basalt formation in borehole c4997 
WMP-31815, Rev. 0

This page intentionally left blank. 
WMP-31815, Rev. 0

HETHO0: 6RP-EE-01-7.0
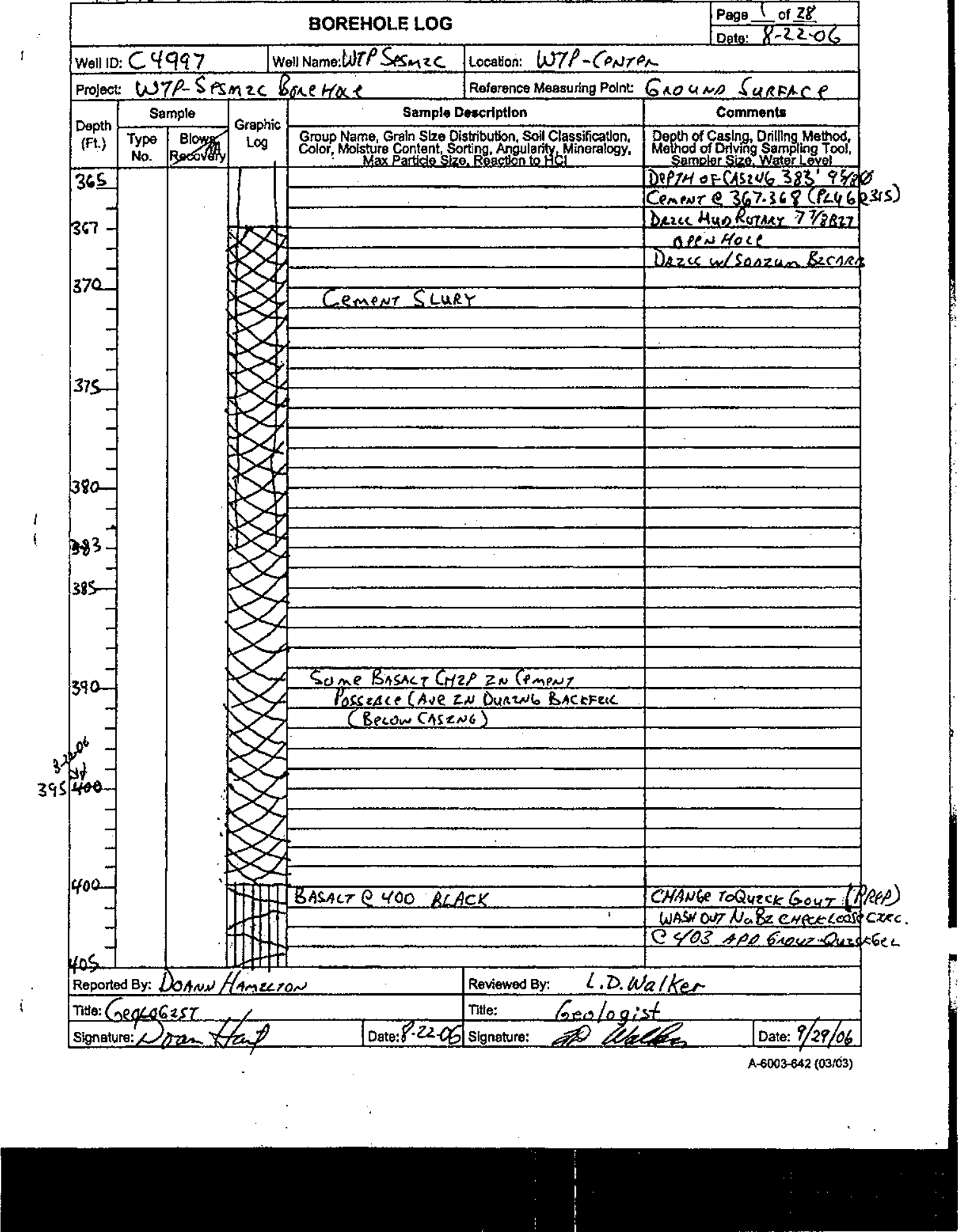
WMP-31815, Rev. 0

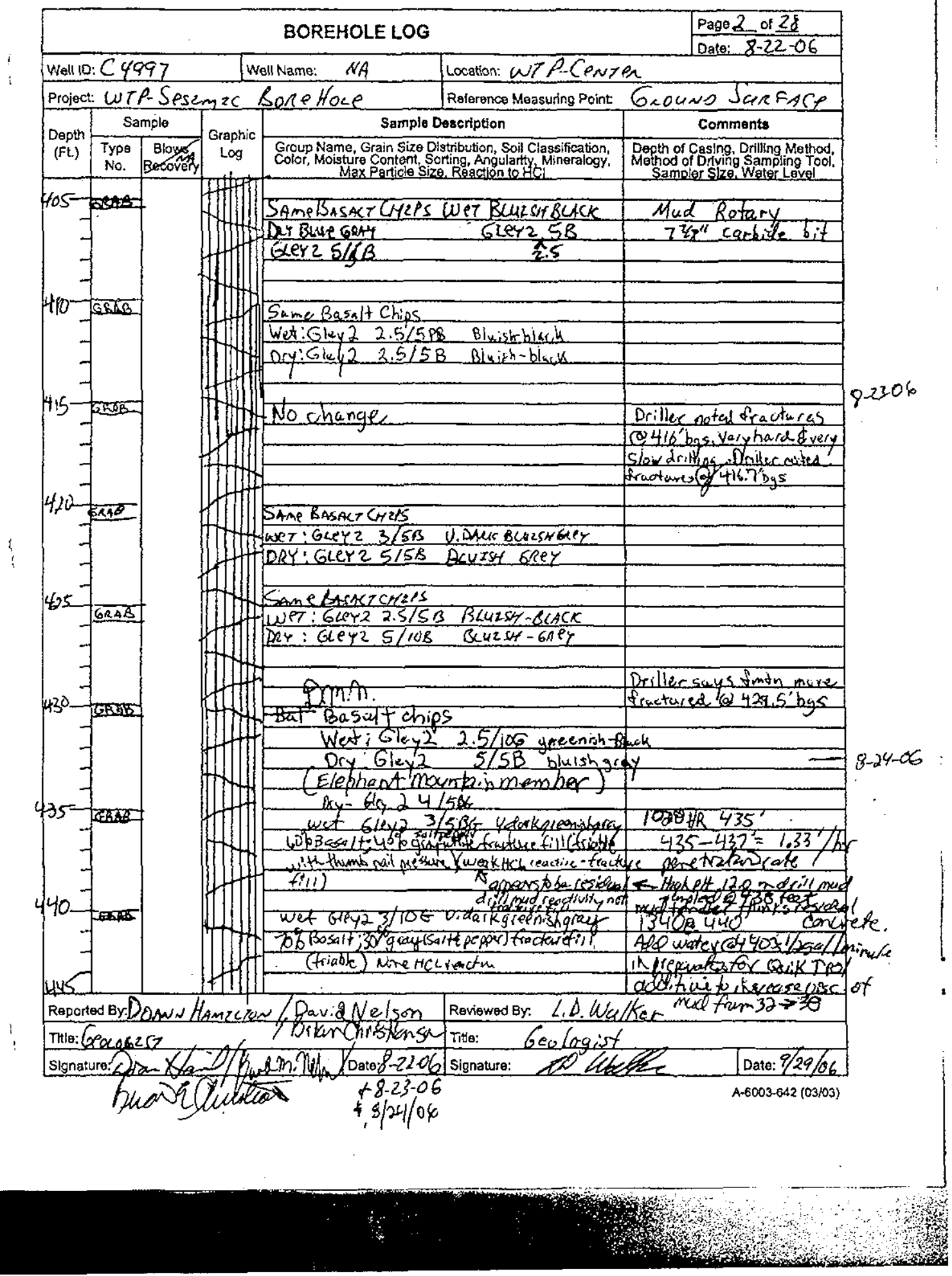


WMP-31815, Rev. 0

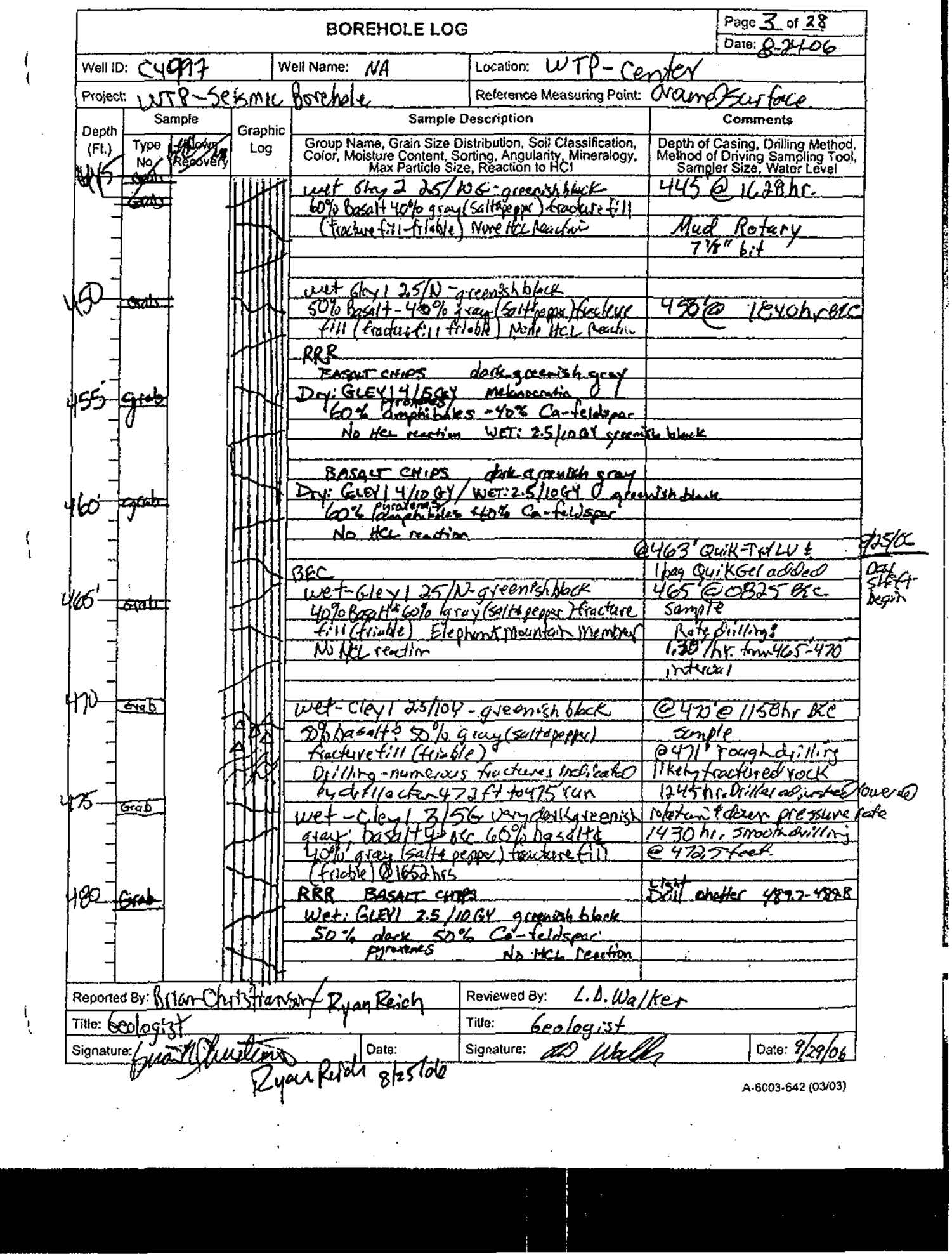


WMP-31815, Rev. 0

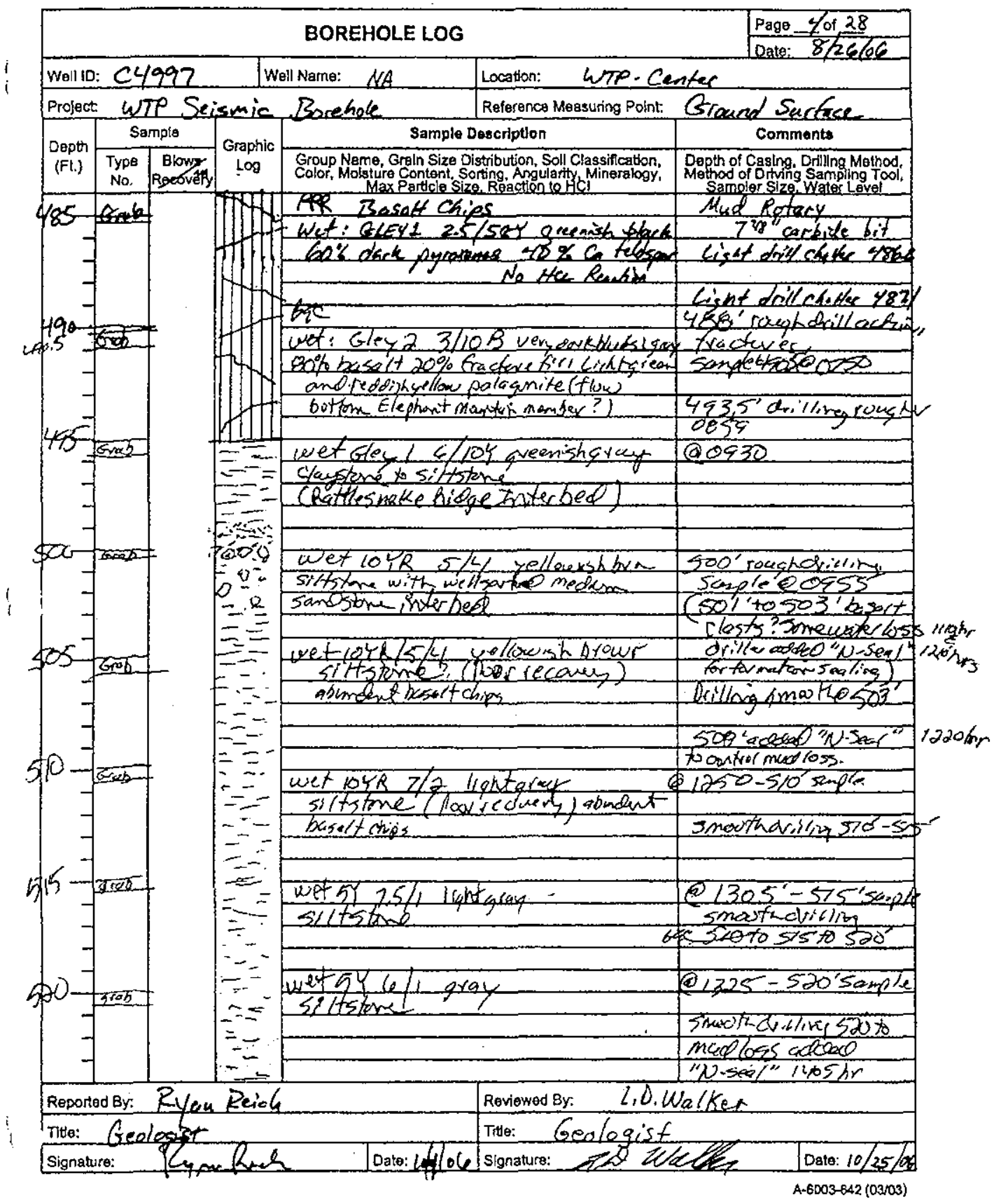




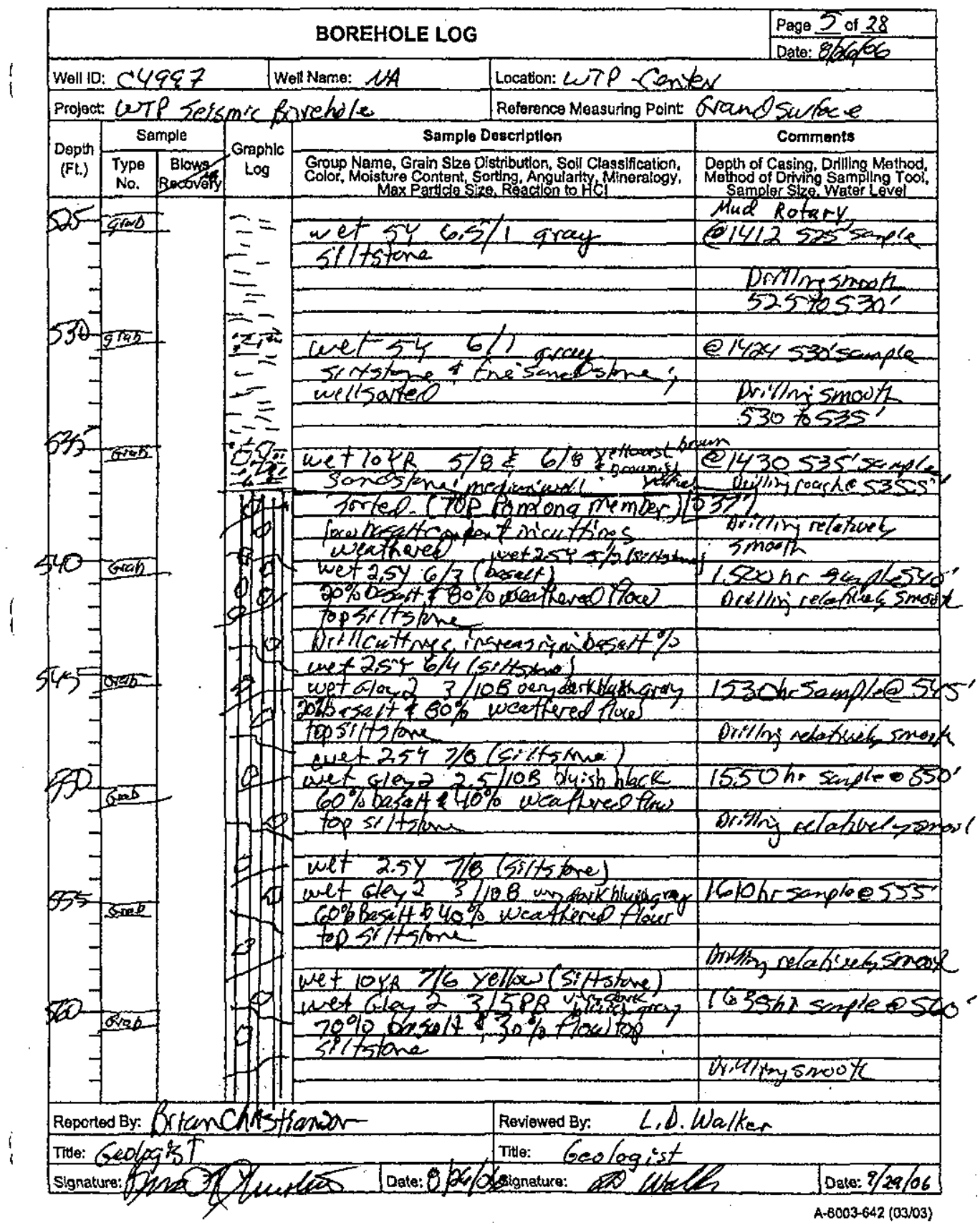


WMP-31815, Rev. 0

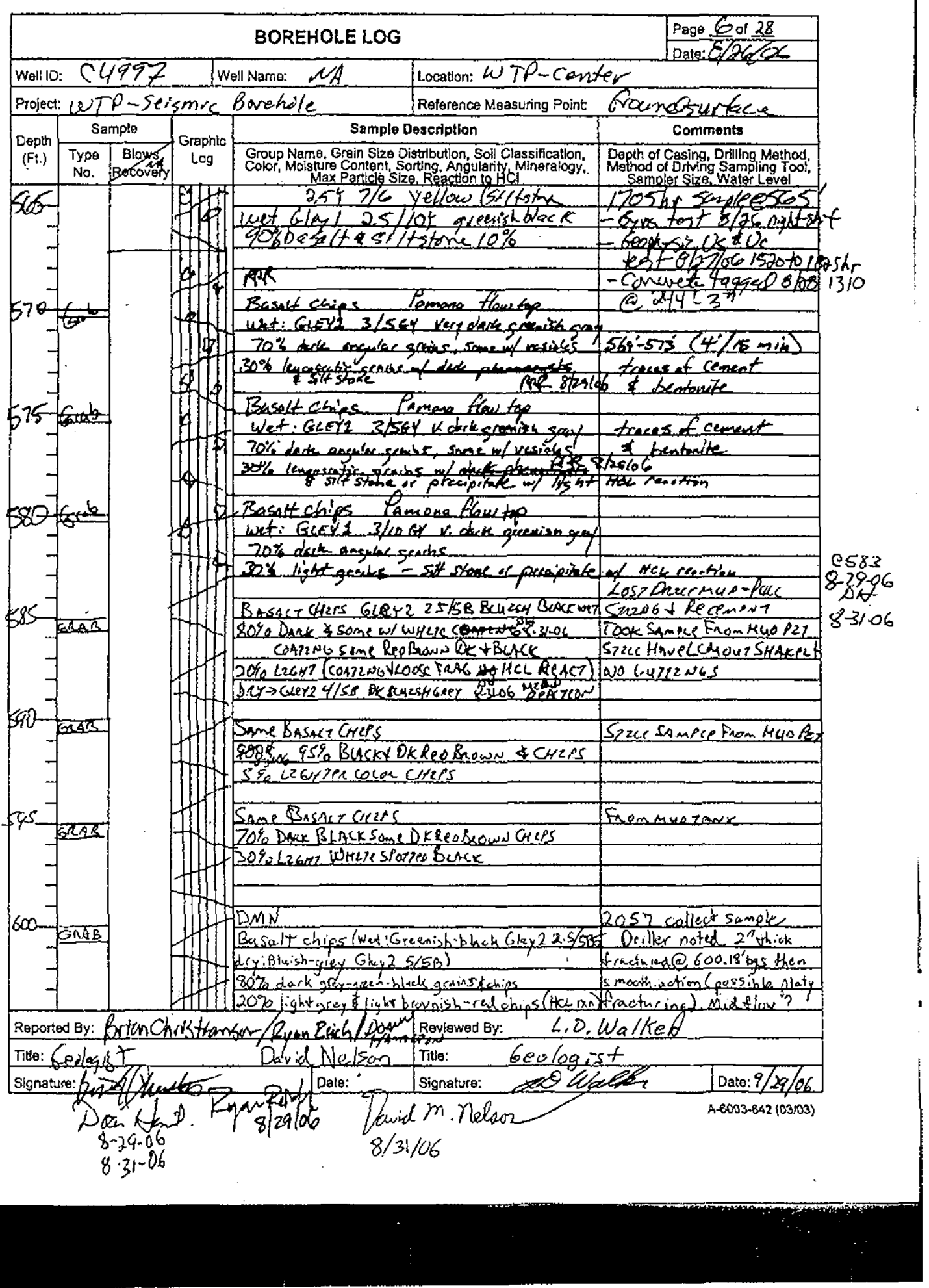




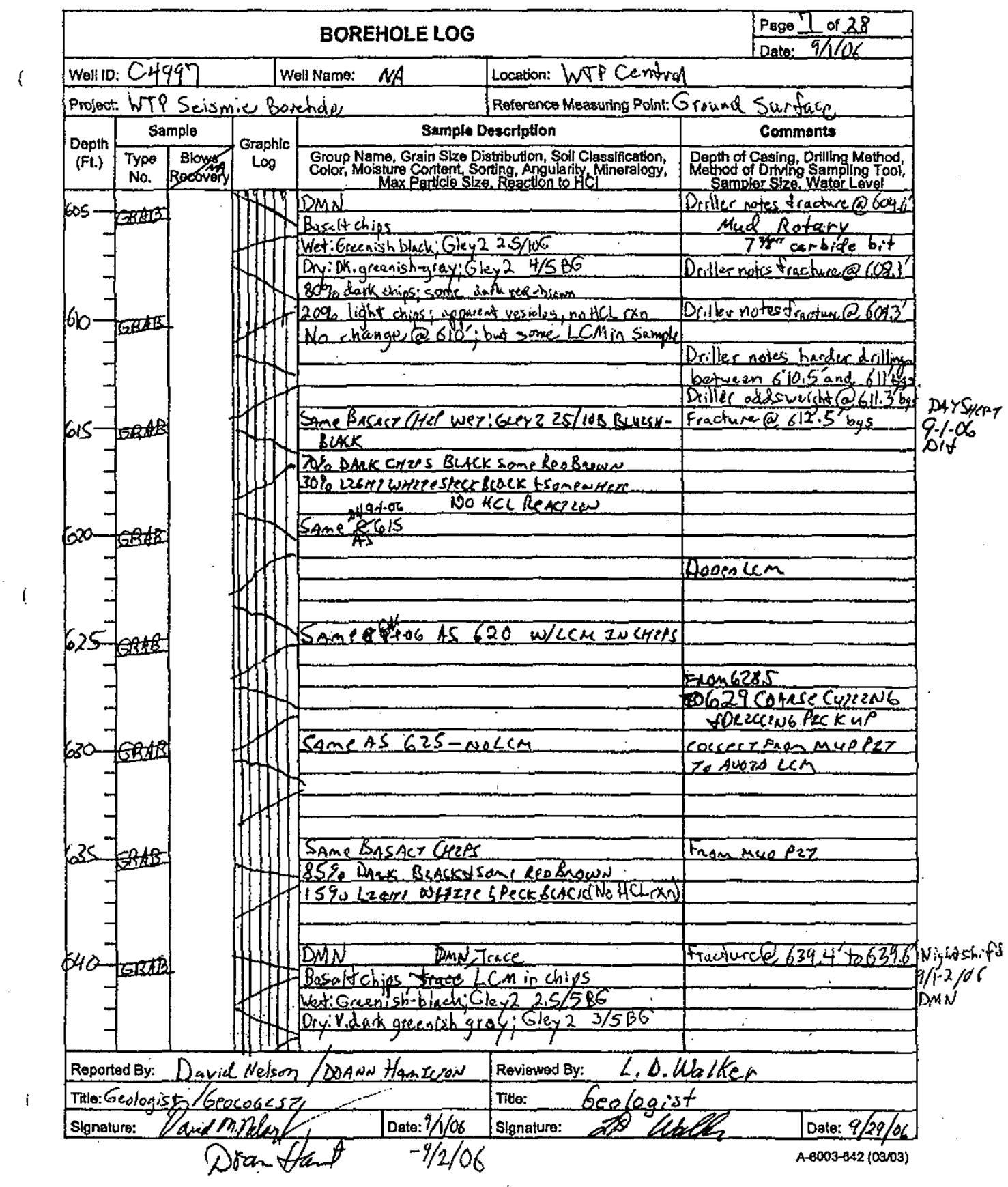


WMP-31815, Rev. 0

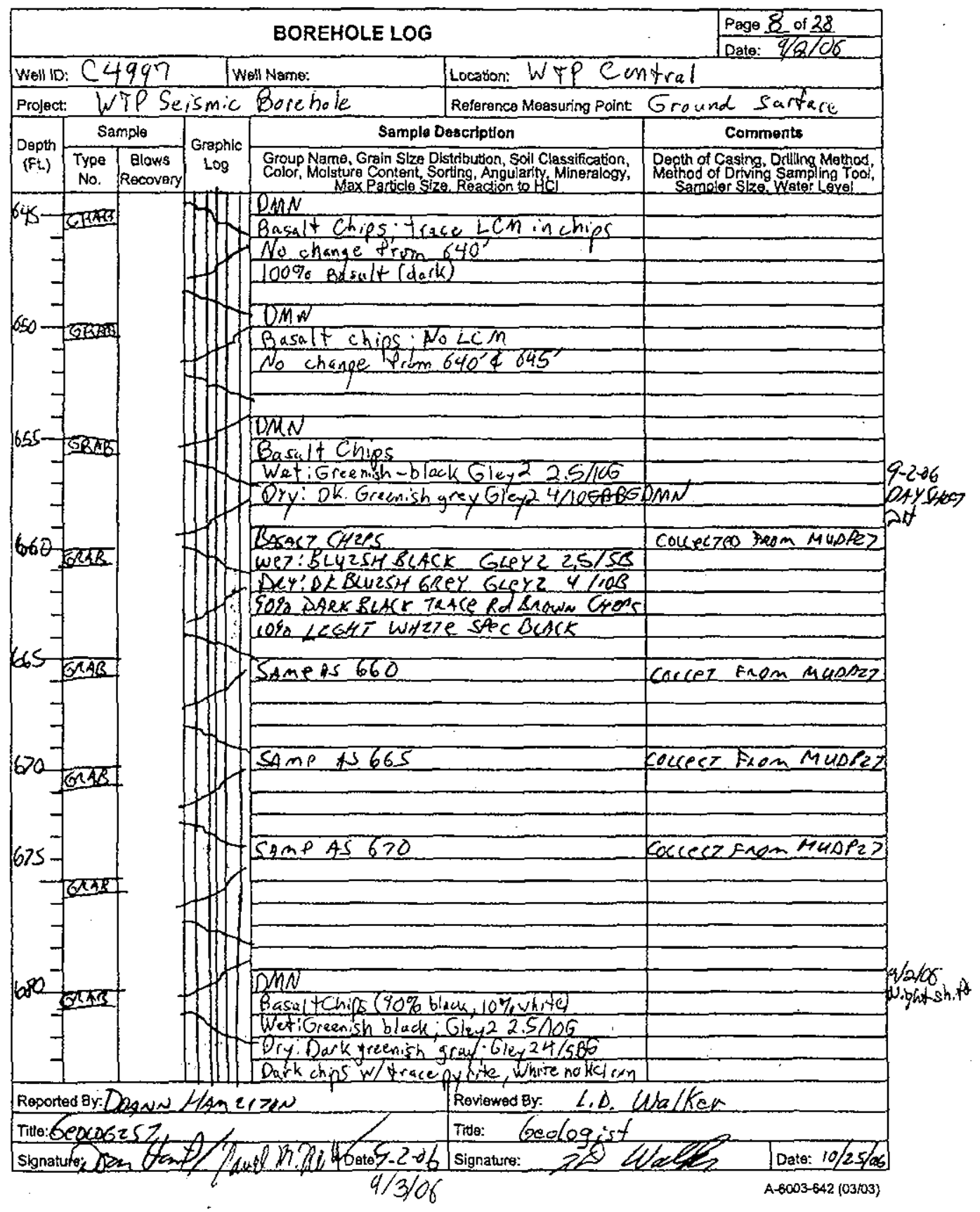


WMP-31815, Rev. 0

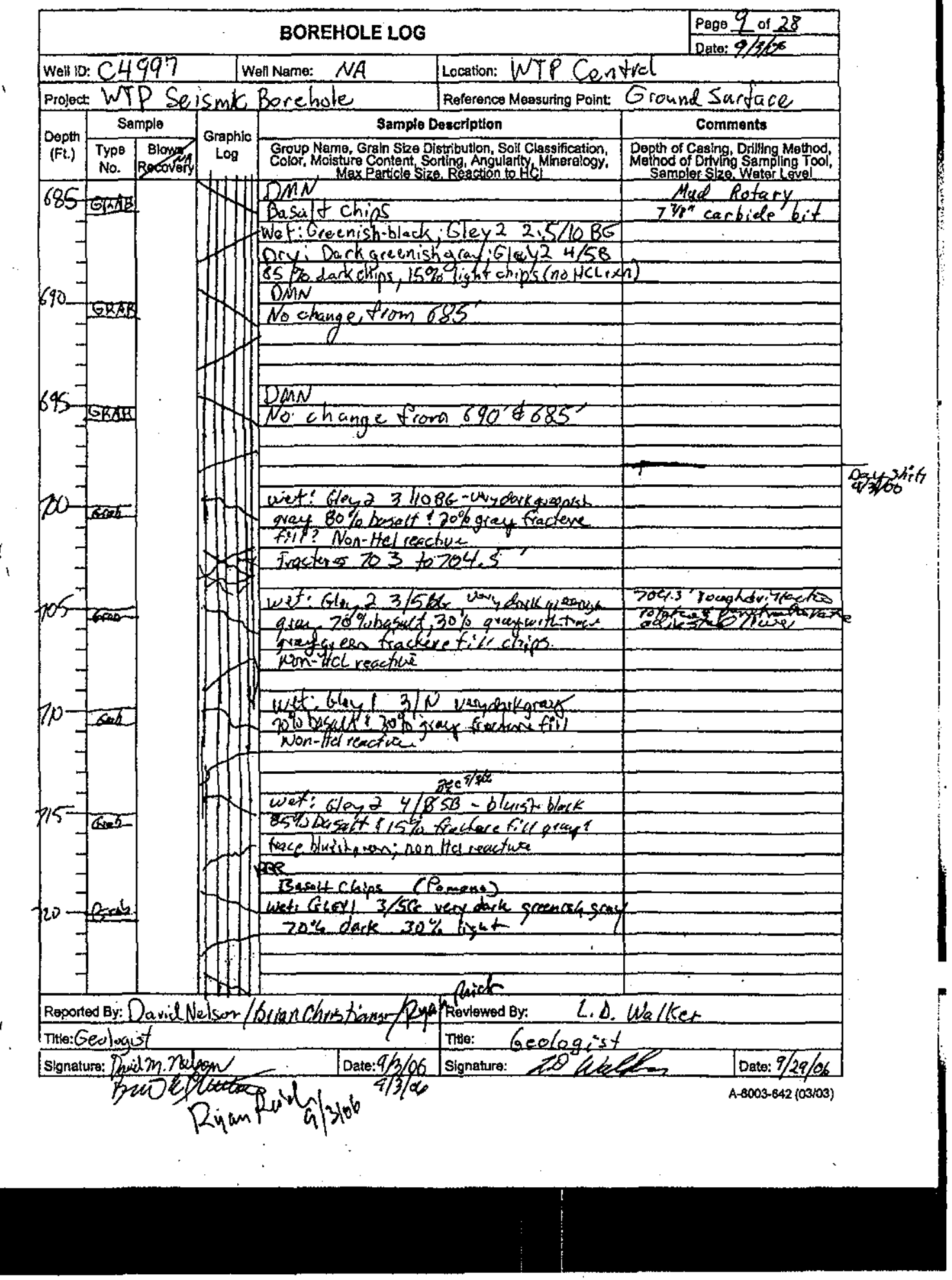




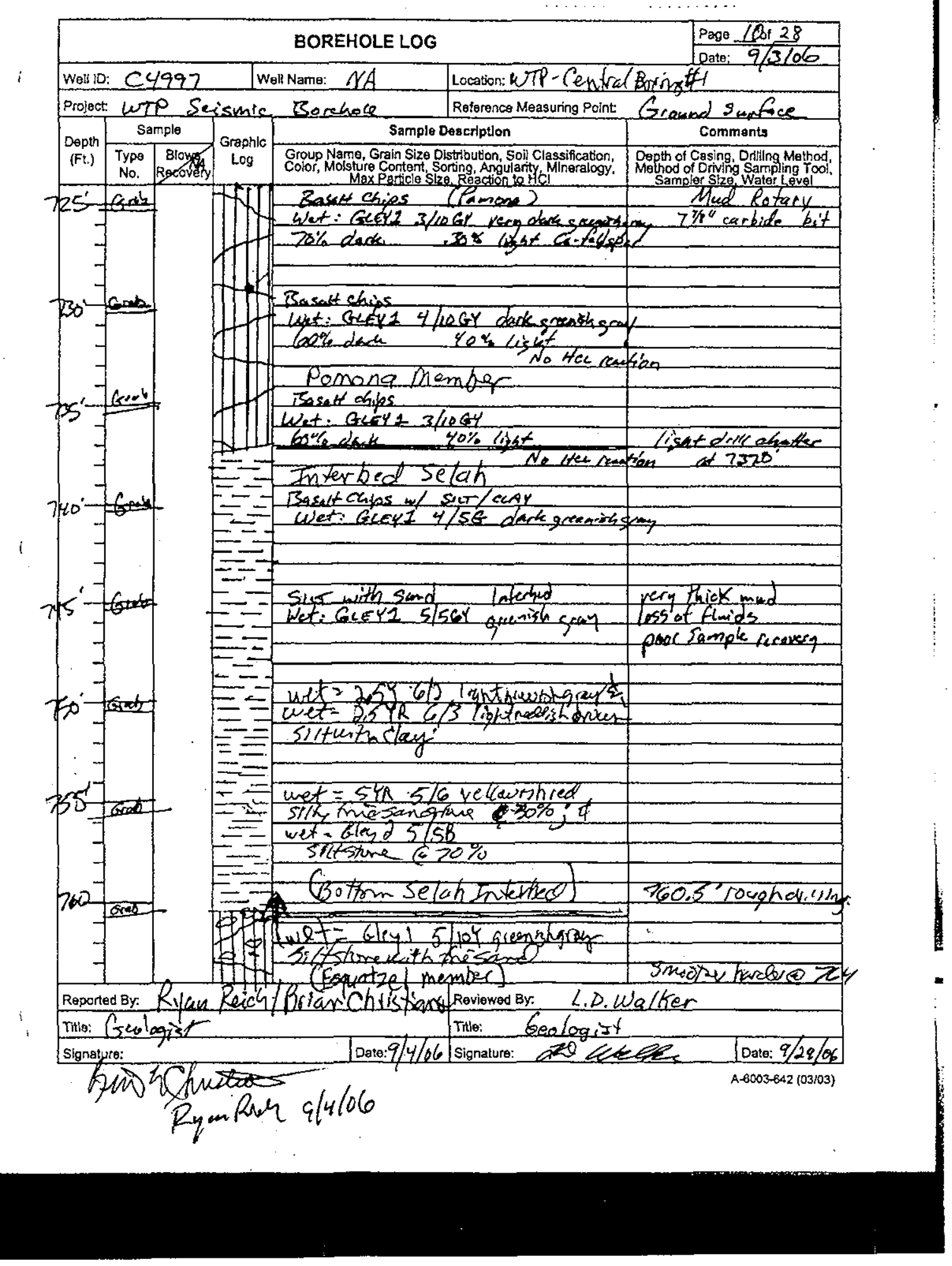


WMP-31815, Rev. 0

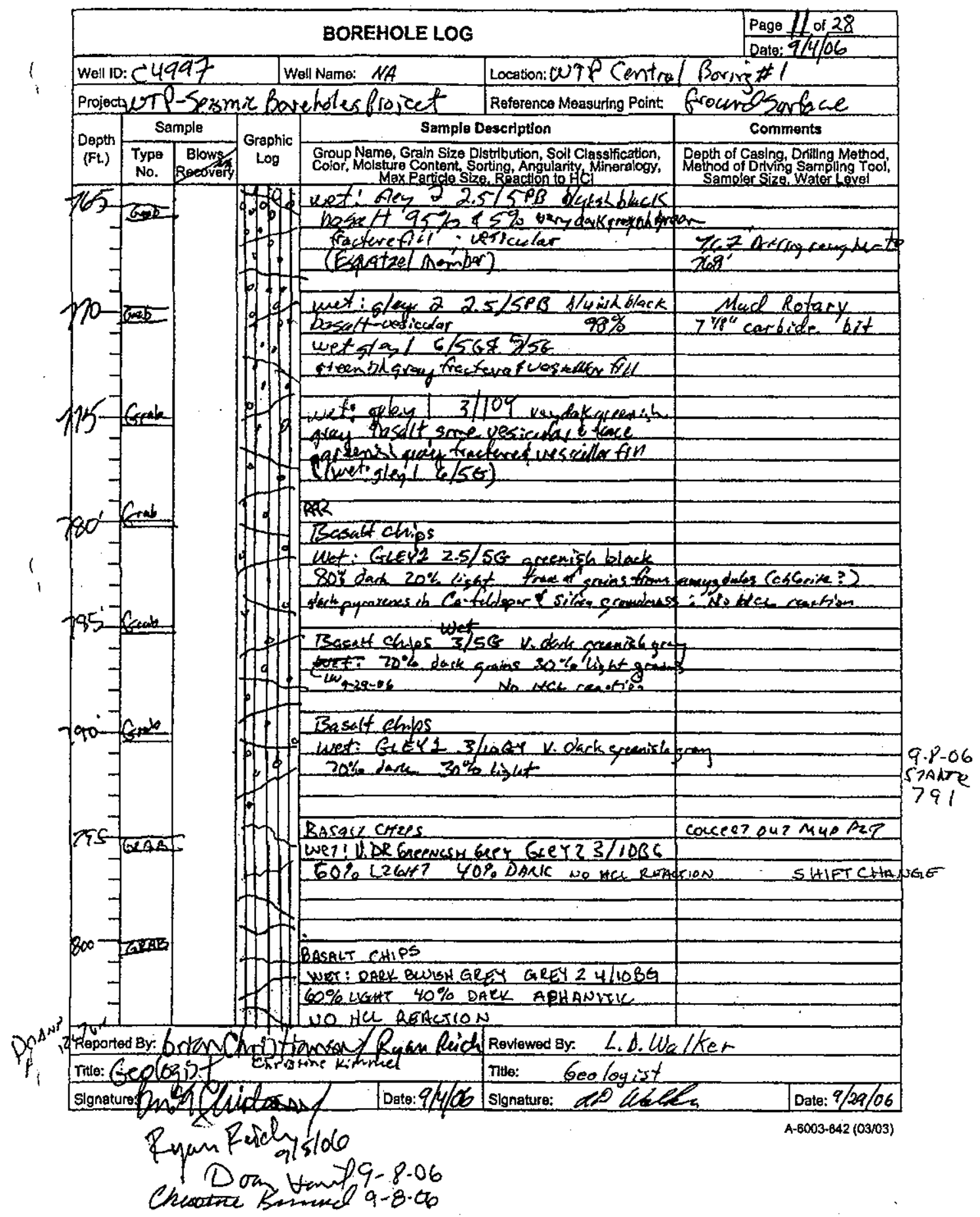




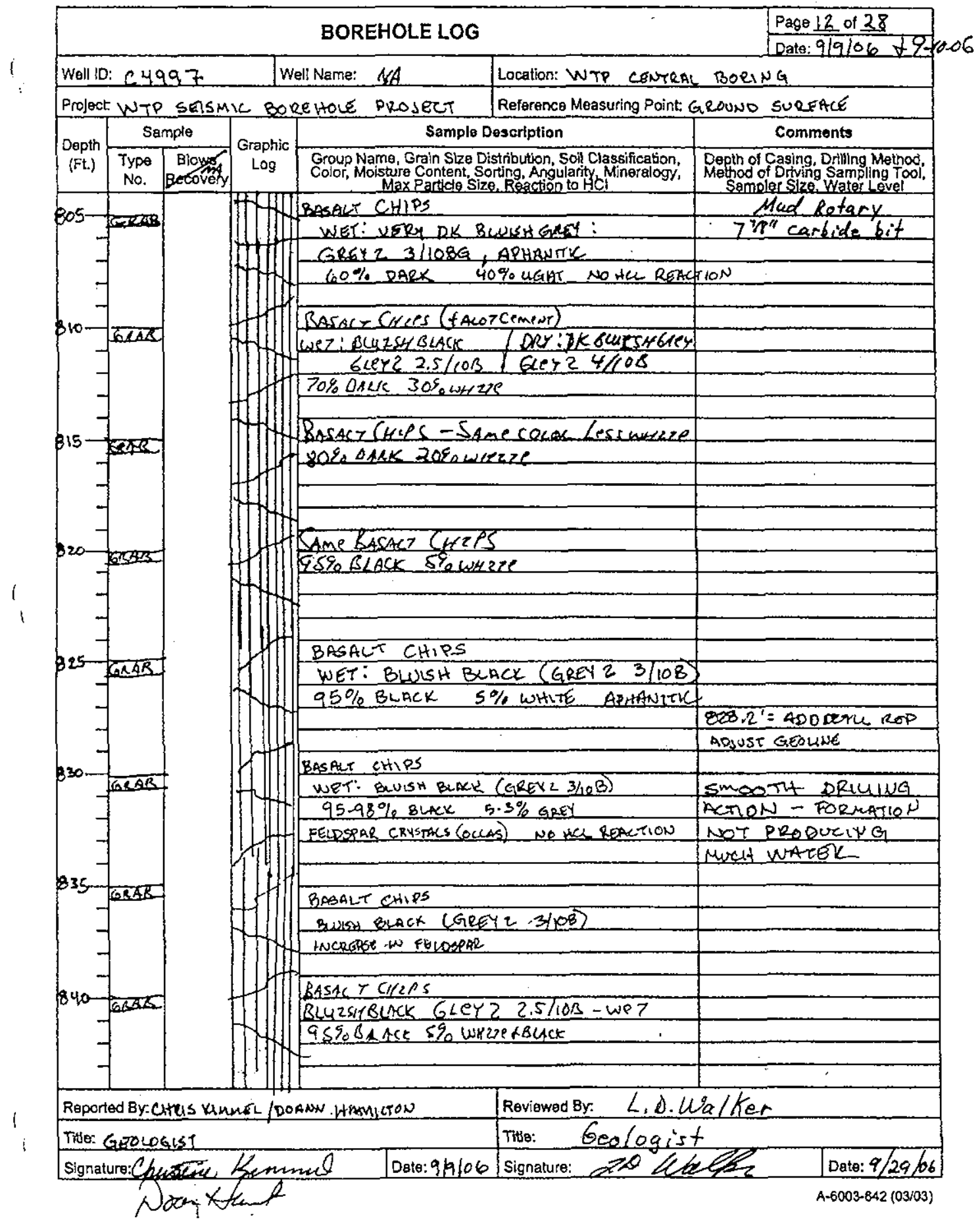




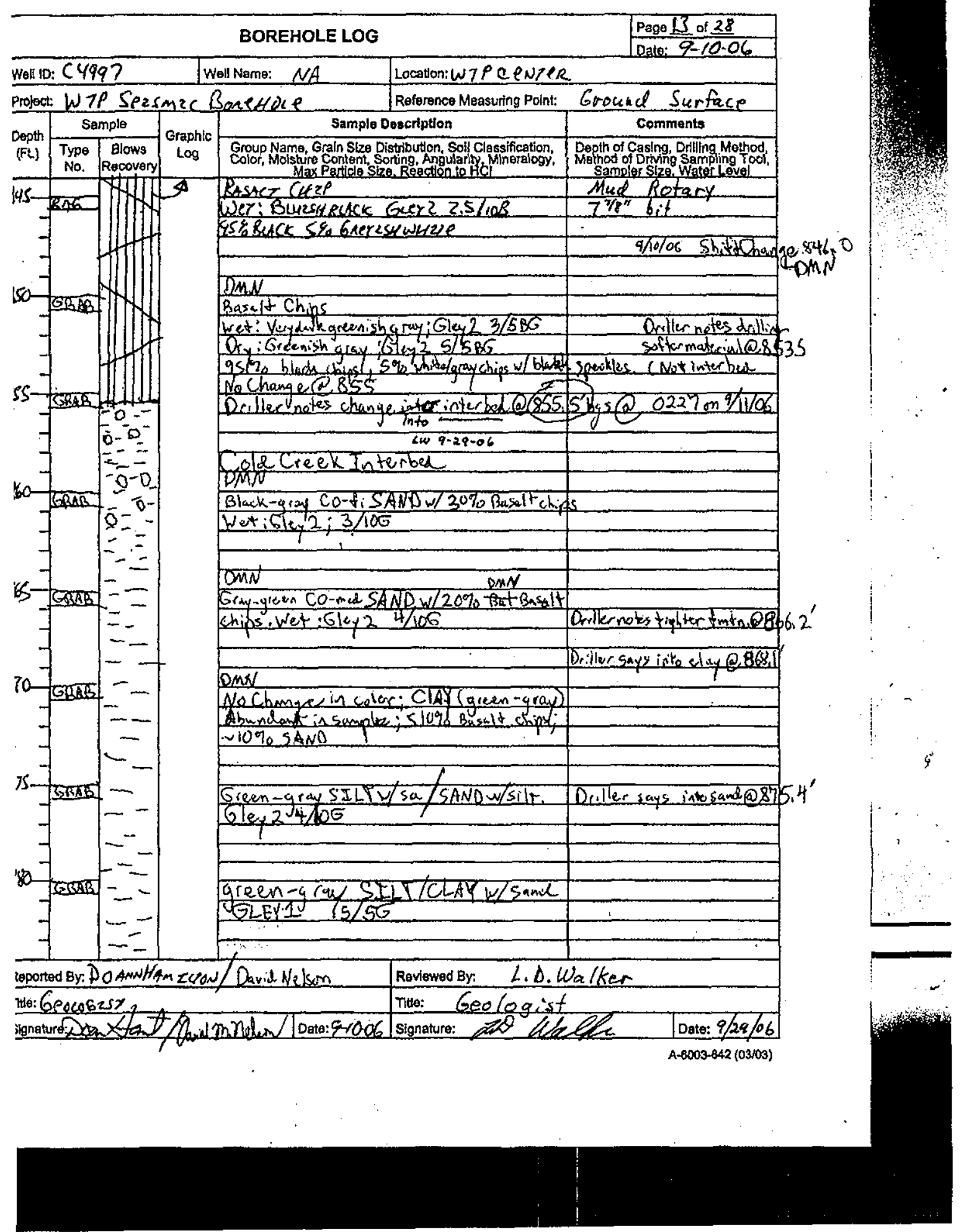


WMP-31815, Rev. 0

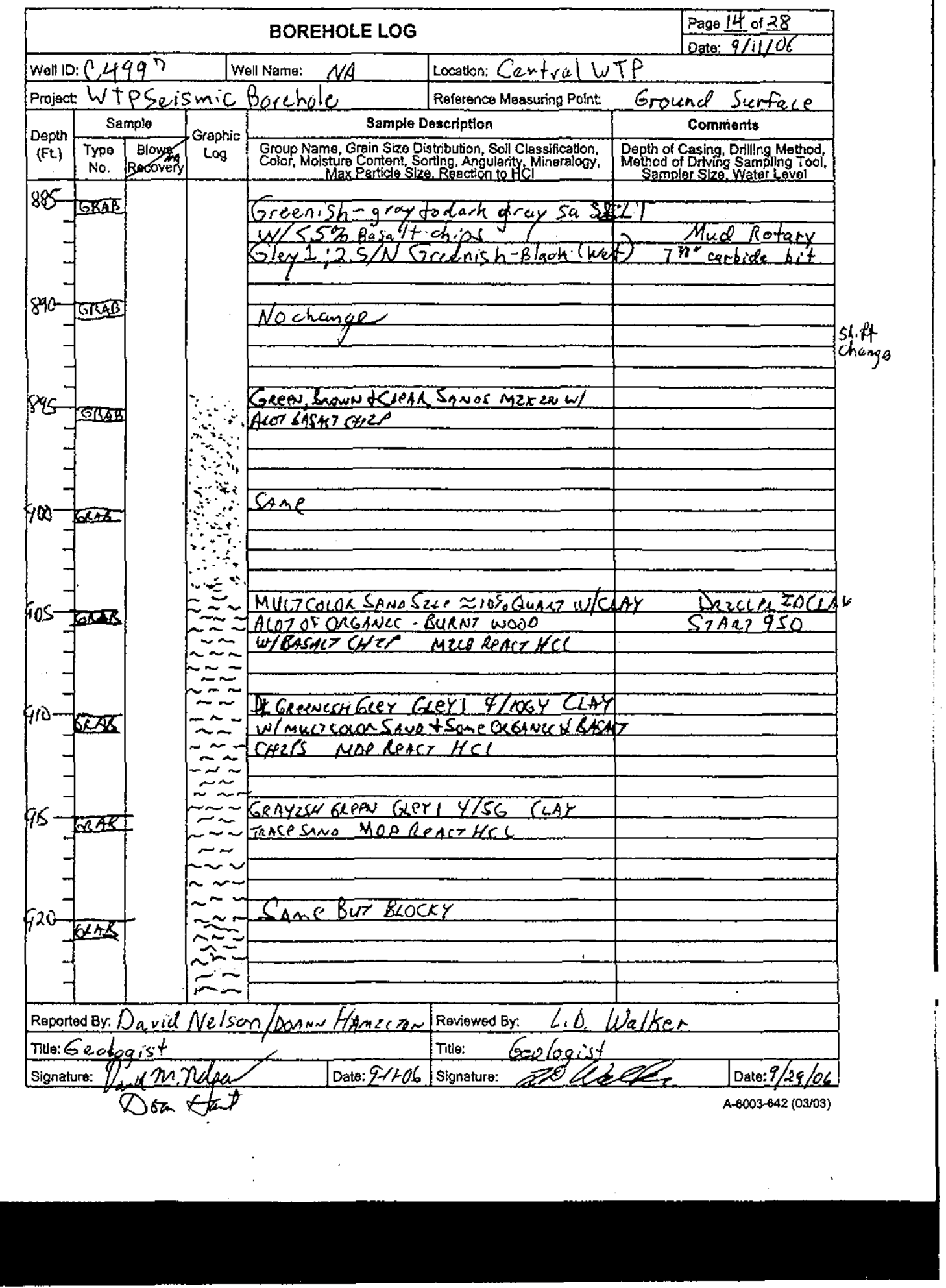


WMP-31815, Rev. 0

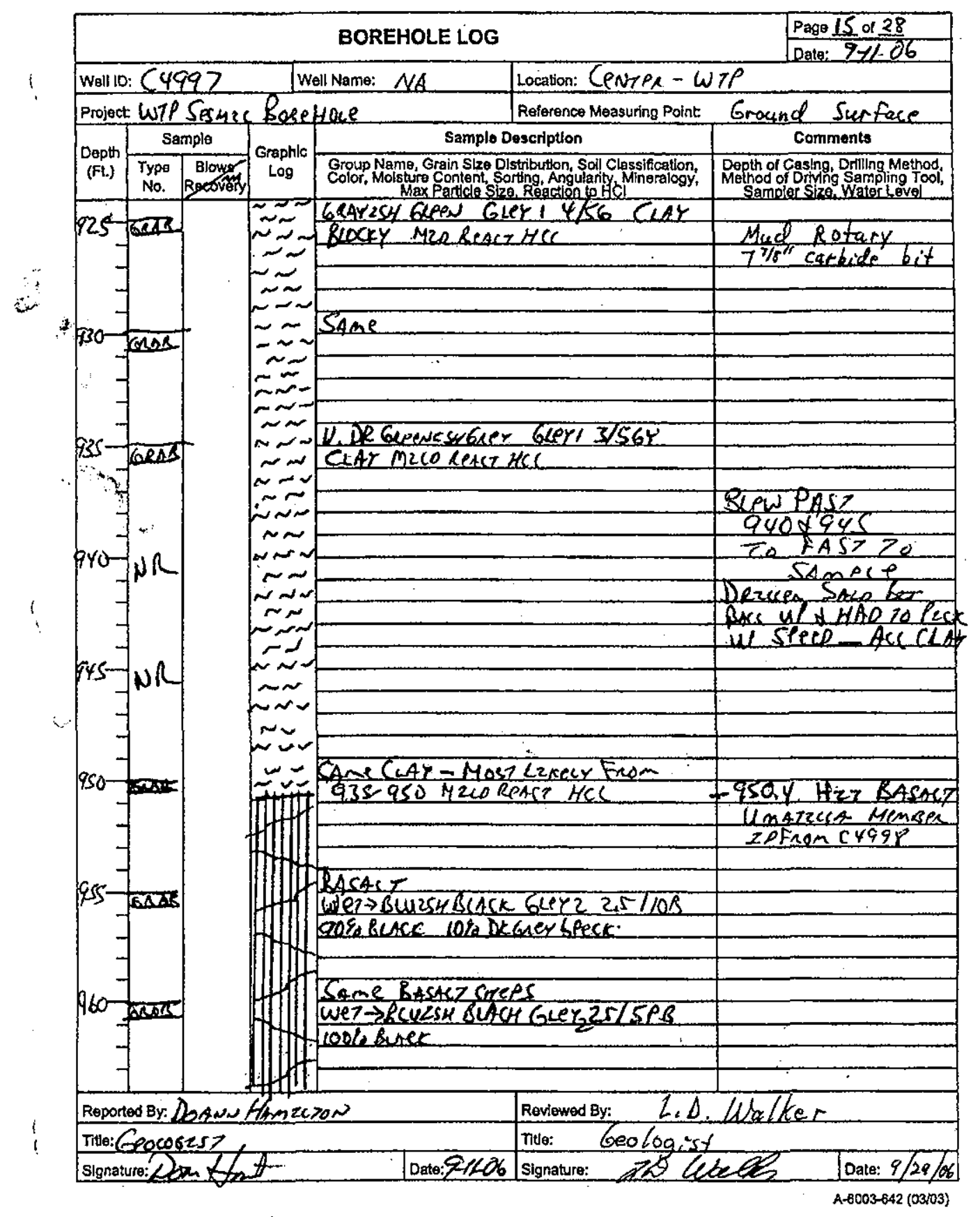


EQM Inc.

1777 Terminal Dr.

Richland, WA 99352

Attn: Ms. Mitzj Miller

RE: LETTER OF AUTWENTICTTY BOREHOLE C4997, LOG PAGE 16 WTP SEISMIC STUdY ProJeCT

Dear Ms. Millet

As you requested, this letter confirms authenticity of the data provided on page 16 of the boring log for Borehole C4997 of the WTP Seismic Study Project at the Hanford site. The two field Geologists who oversaw the drilling of the boring for the target interval specified on page 16 ( 965 to $1005 \mathrm{ft}$ below ground surface) have review the data and indicate as signatories to this letter, that the data presented on page 16 is a fair and accurate accounting of the observed drill cuttings and that no alterations have been performed. A copy of page 16 is attached for your reference.

If you have any questions related to the contents of this letter, please feel free to contact Christine Kimmel, Landau Associates' Project Manager at (425)778-0907.

\section{LANDAU ASSOCIATES, INC.}

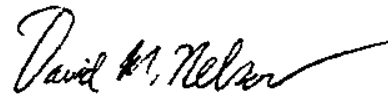

David M. Neison

Staff Geologist
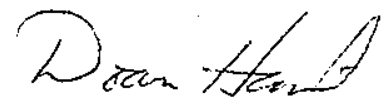

Doann M. Hamilion

Staff Geologist

$$
\text { Qhuatur Linine }
$$

Christine B. KimmeI, L.G.

Senior Project Geologist

CBKI

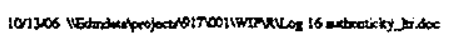

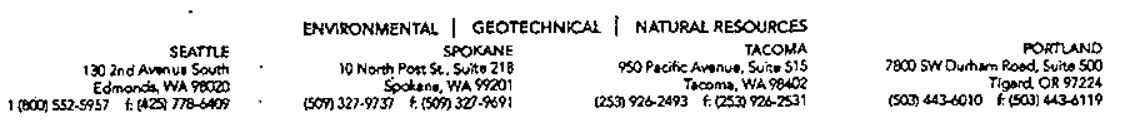


WMP-31815, Rev. 0

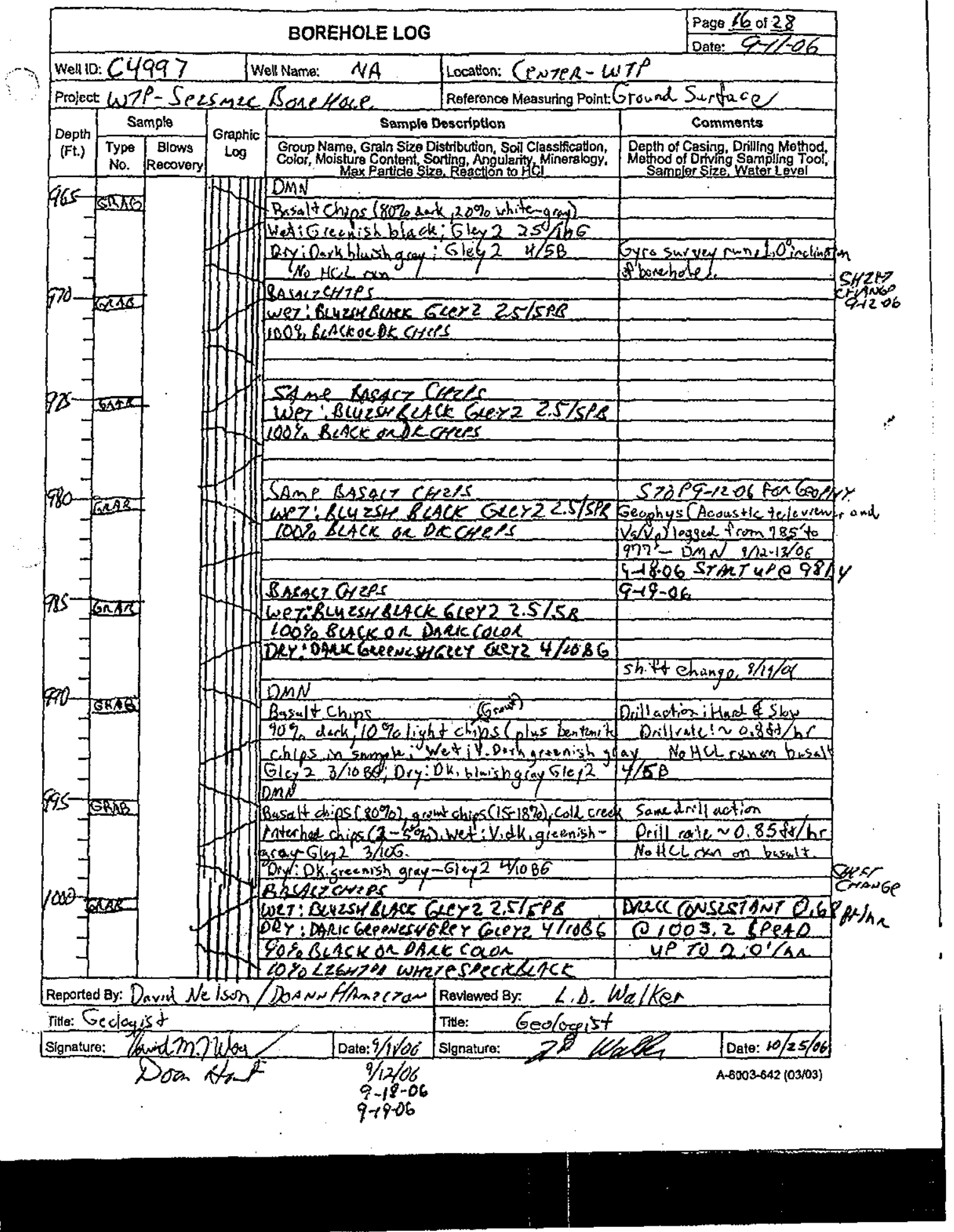




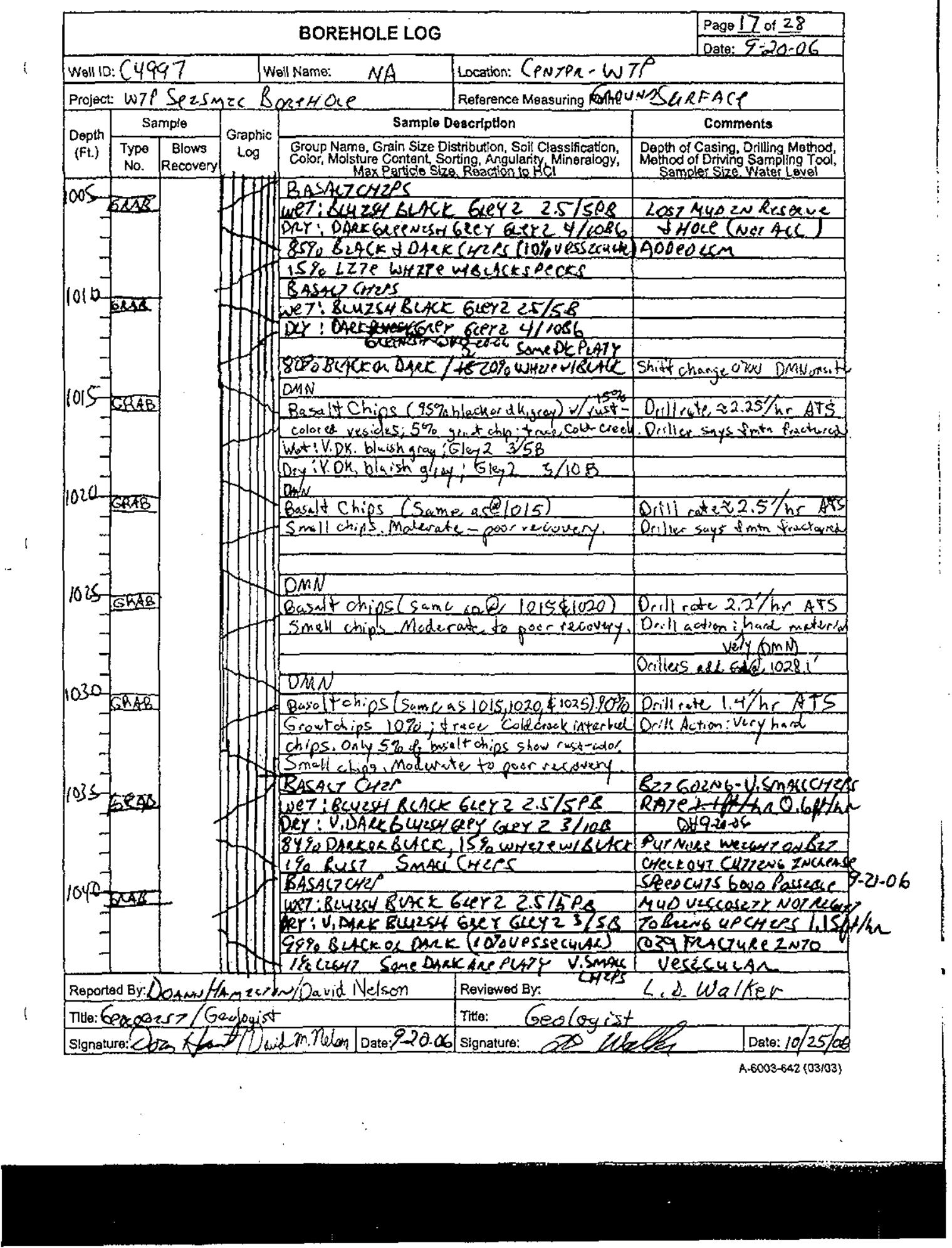



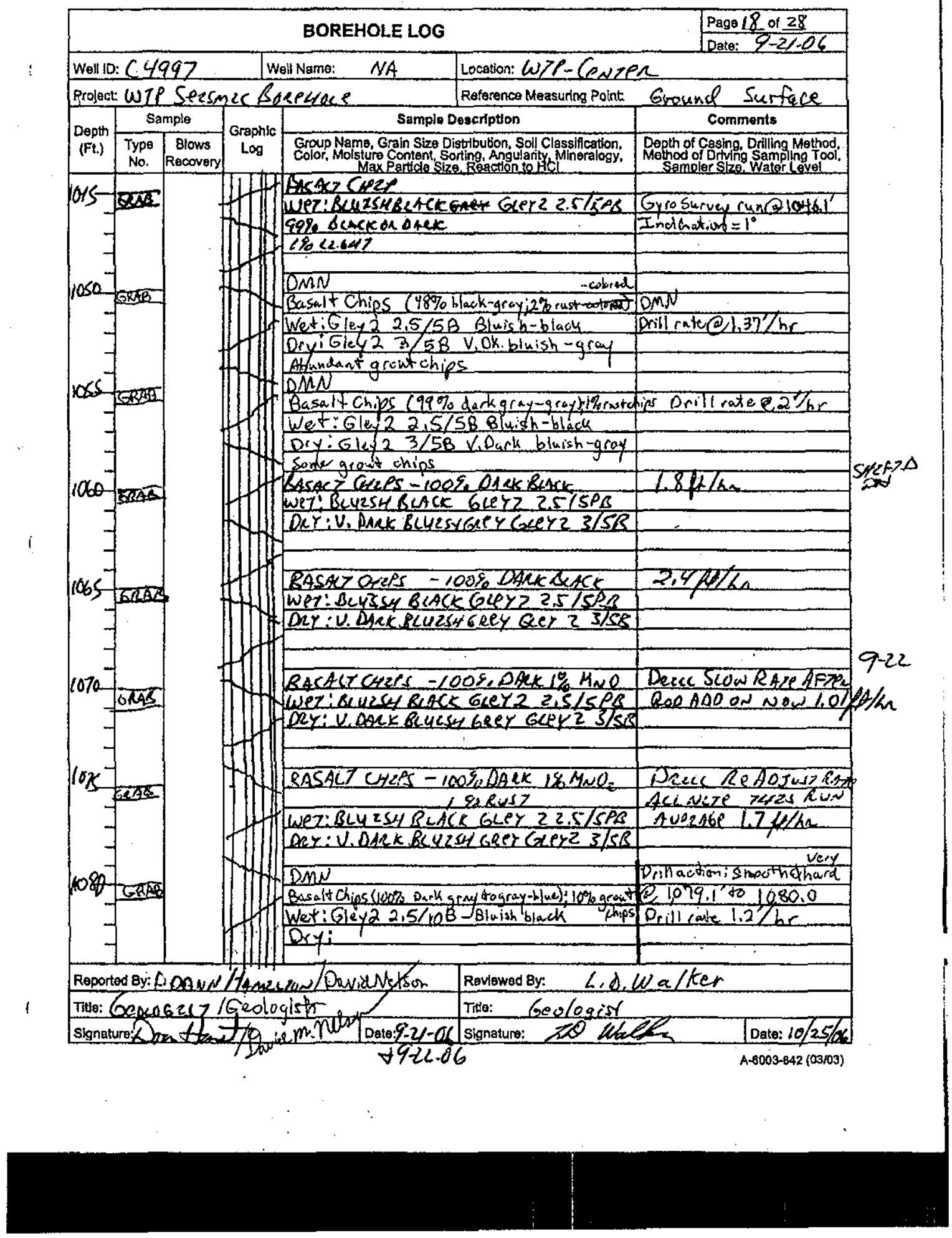
WMP-31815, Rev. 0

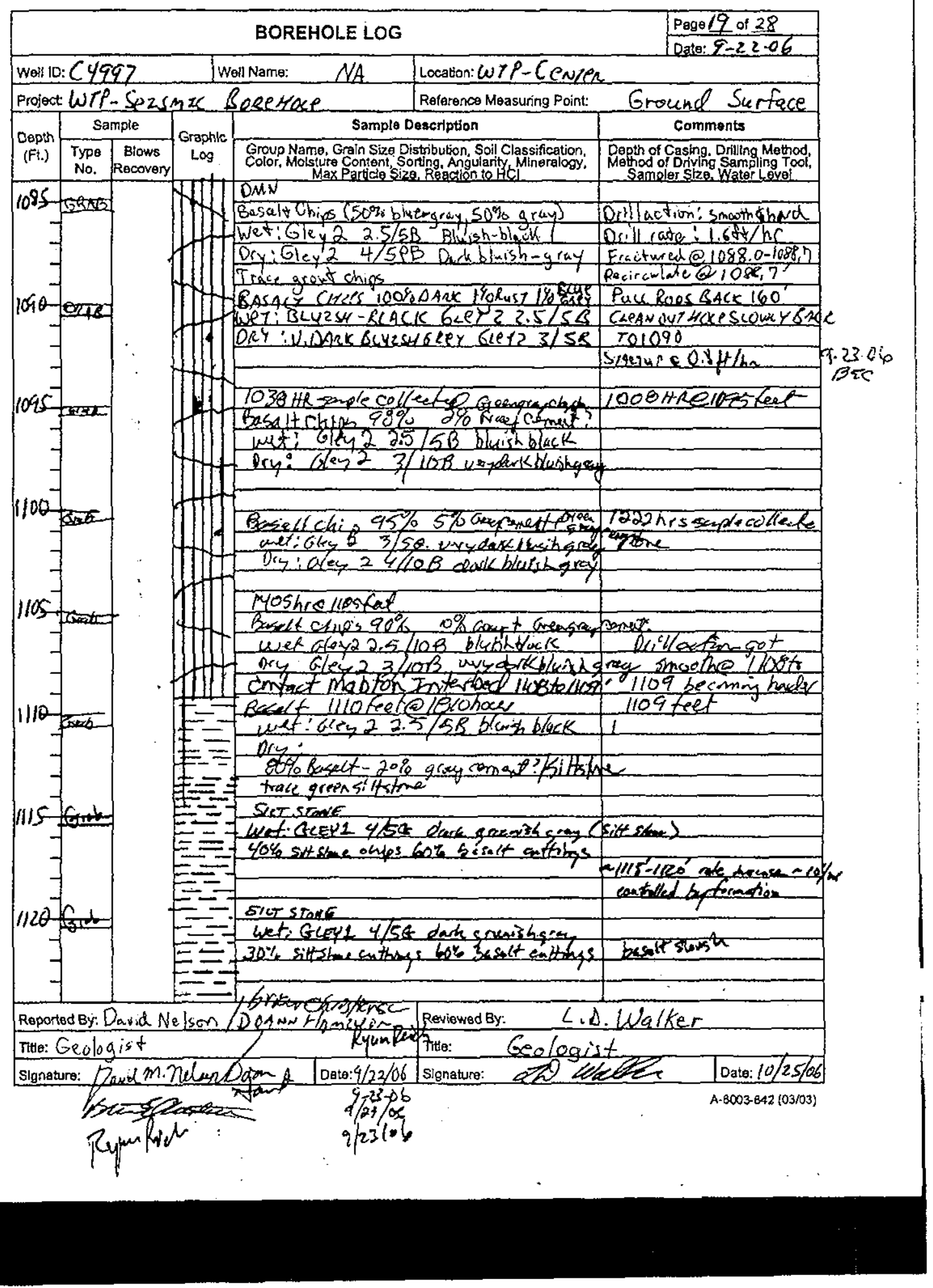




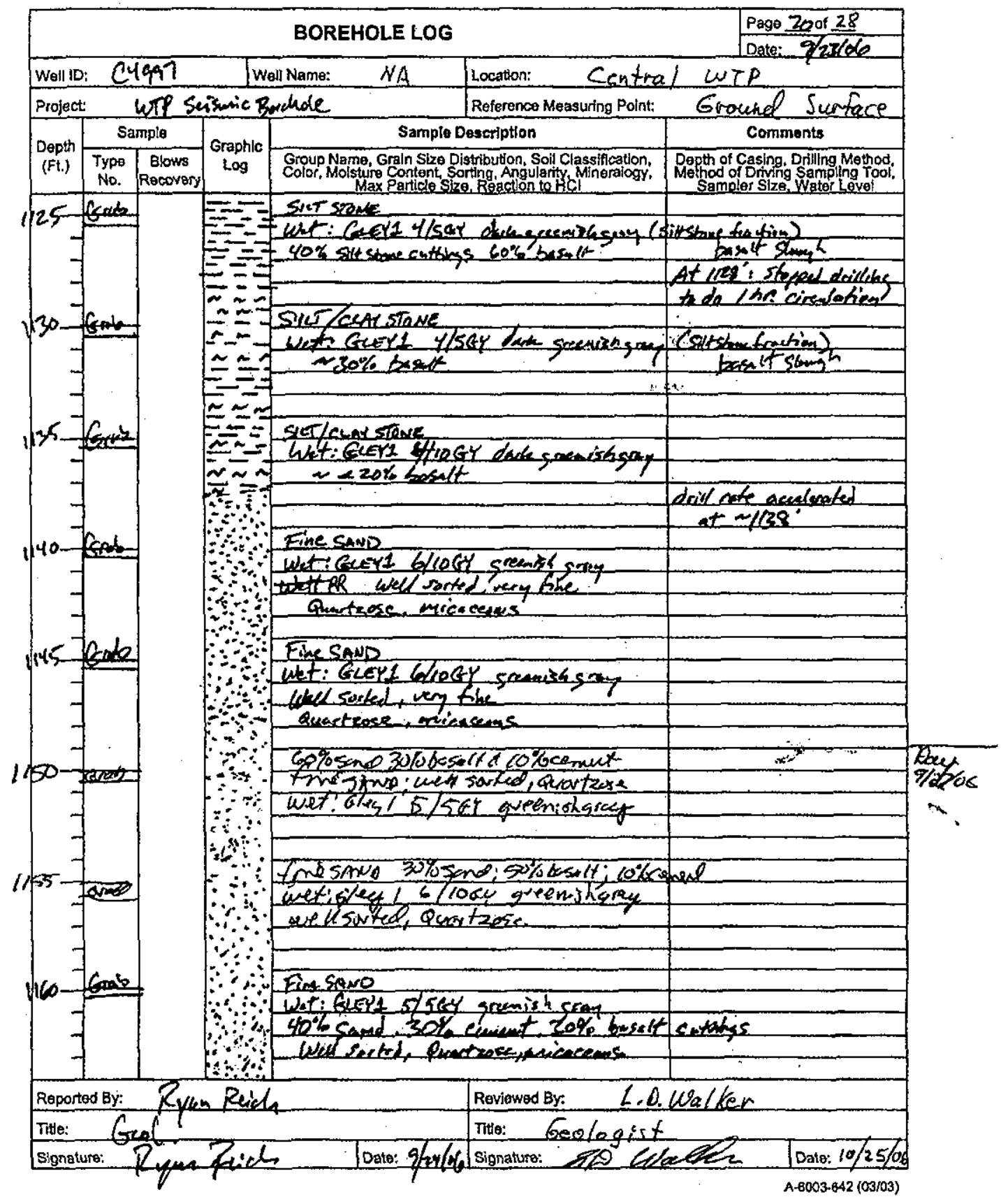


WMP-31815, Rev. 0

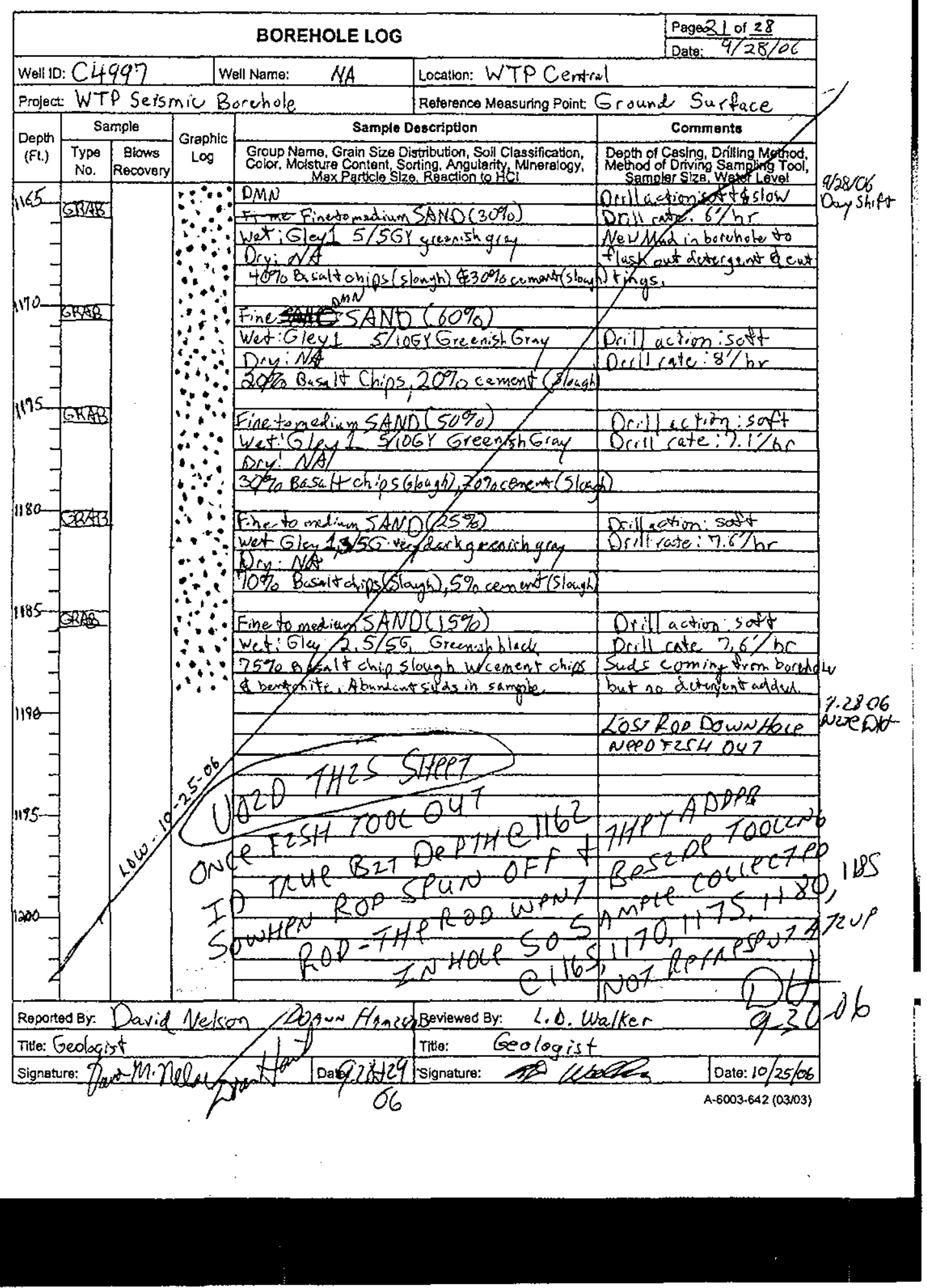




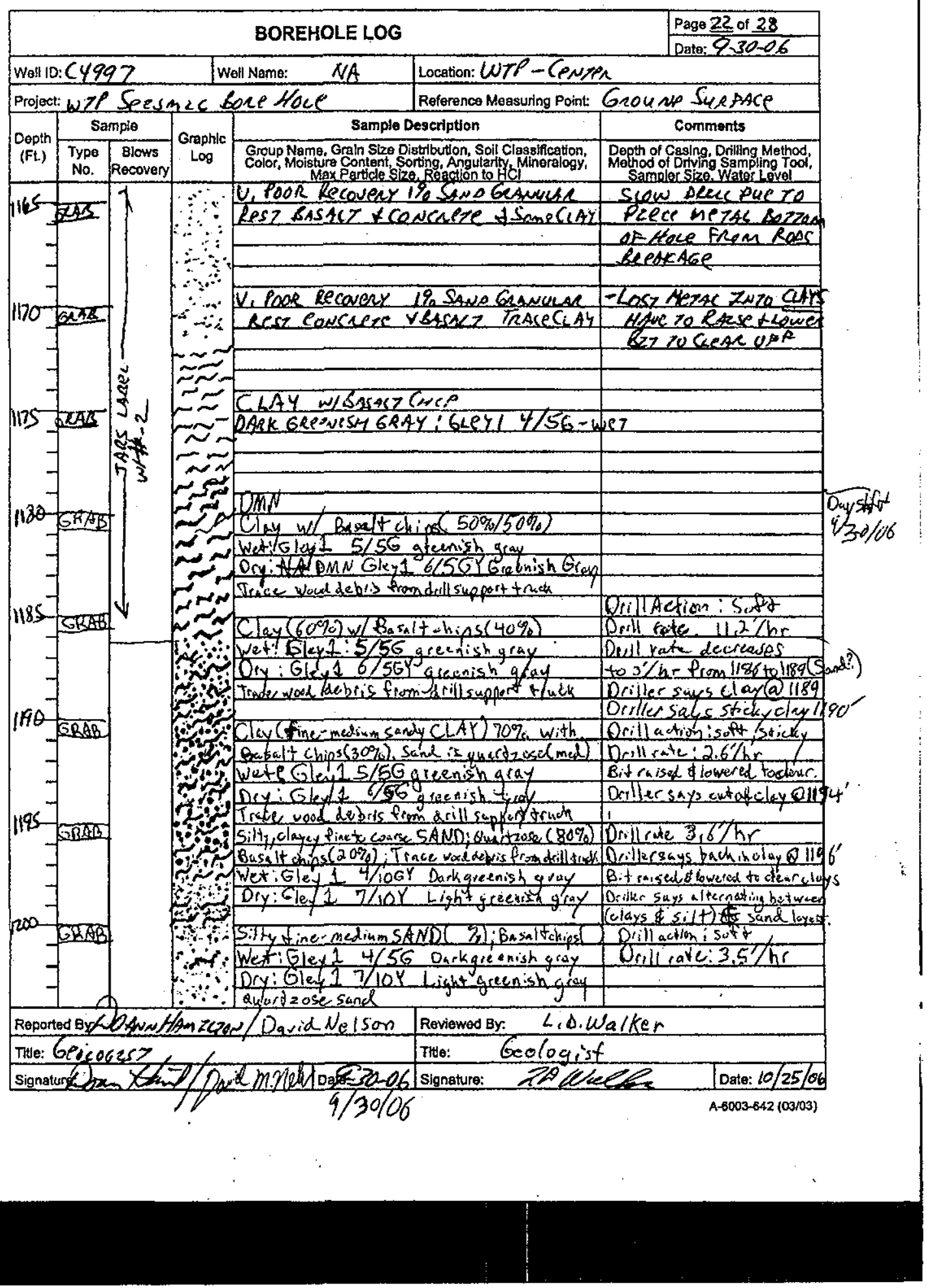


WMP-31815, Rev. 0

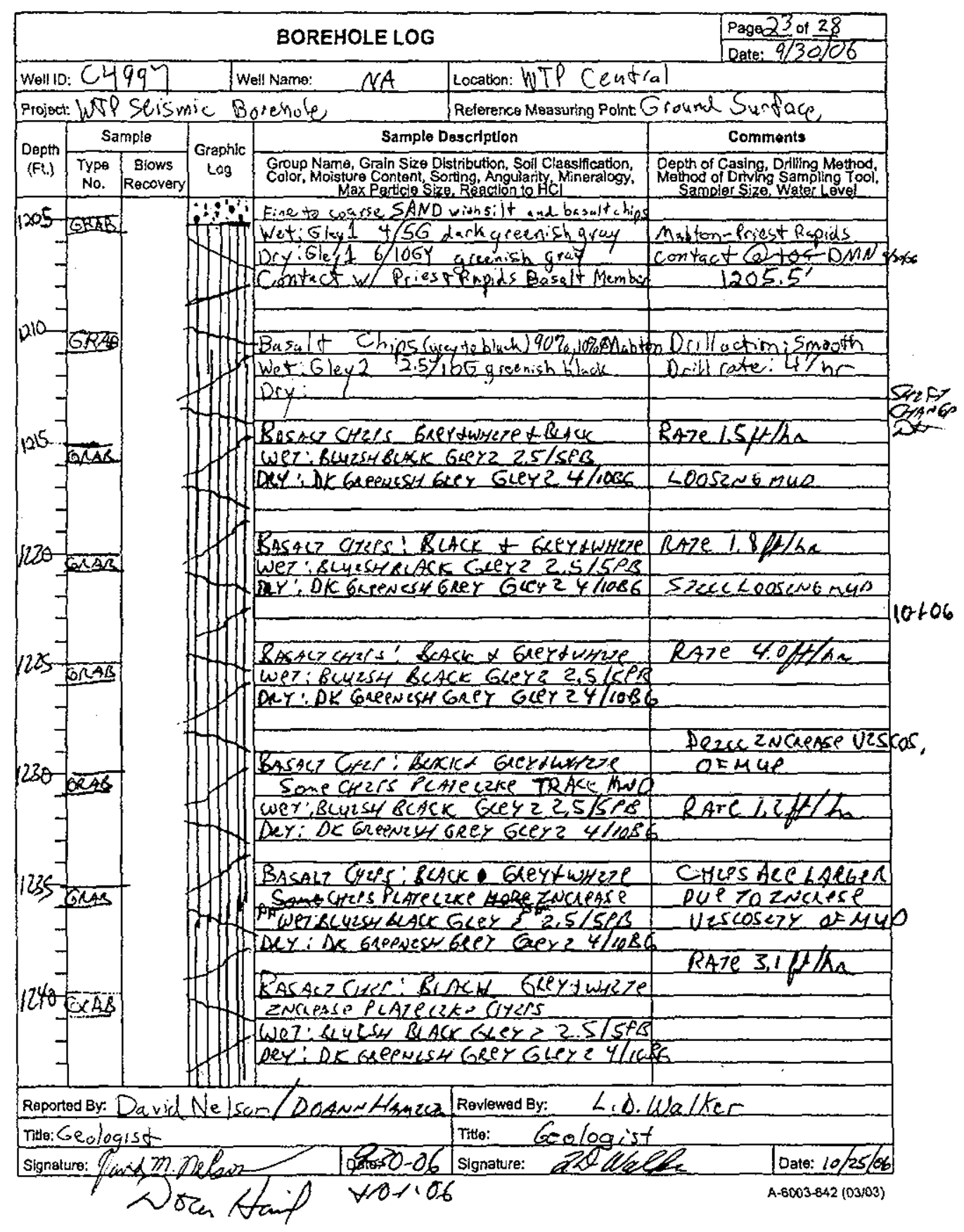




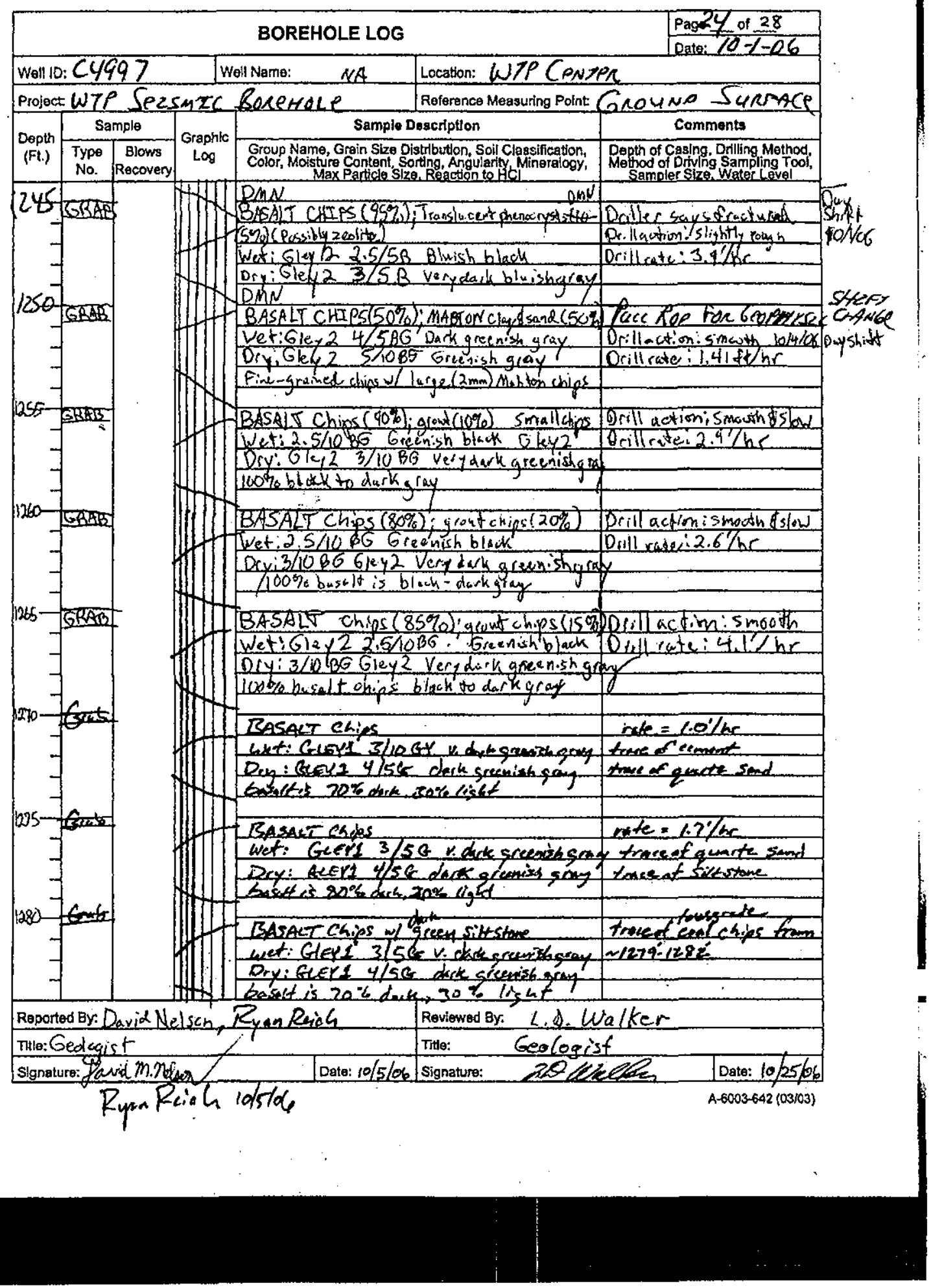




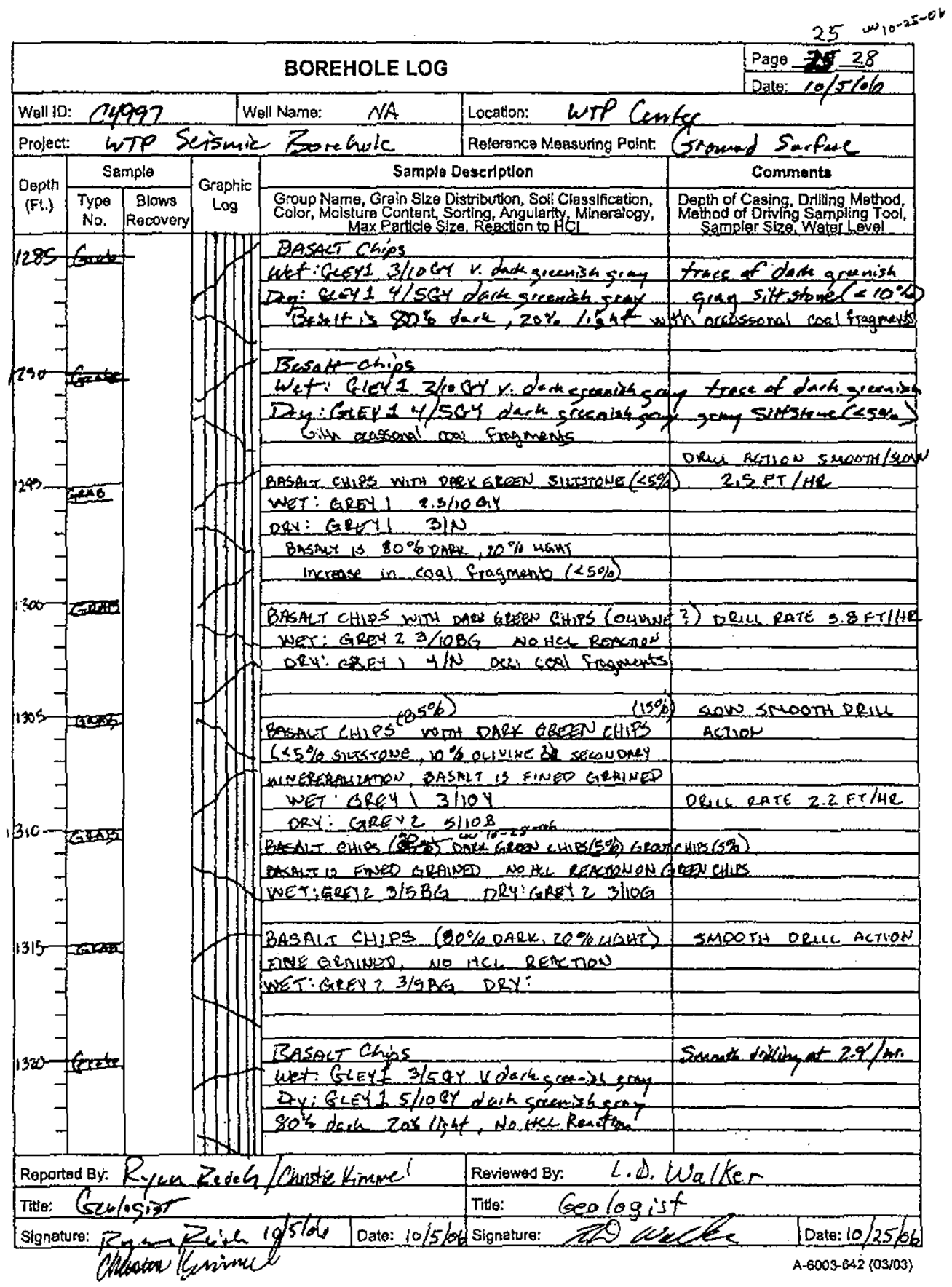


WMP-31815, Rev. 0

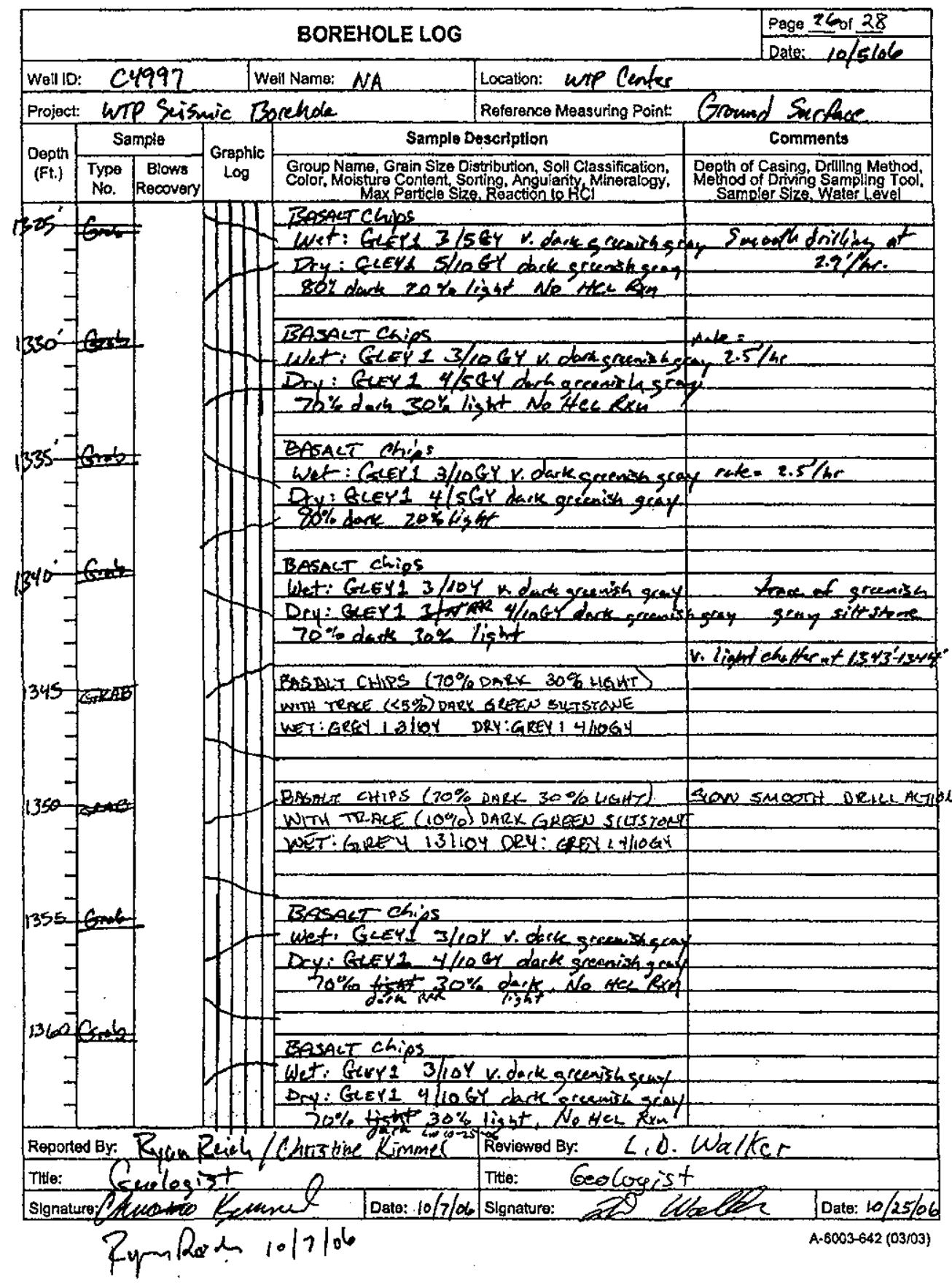




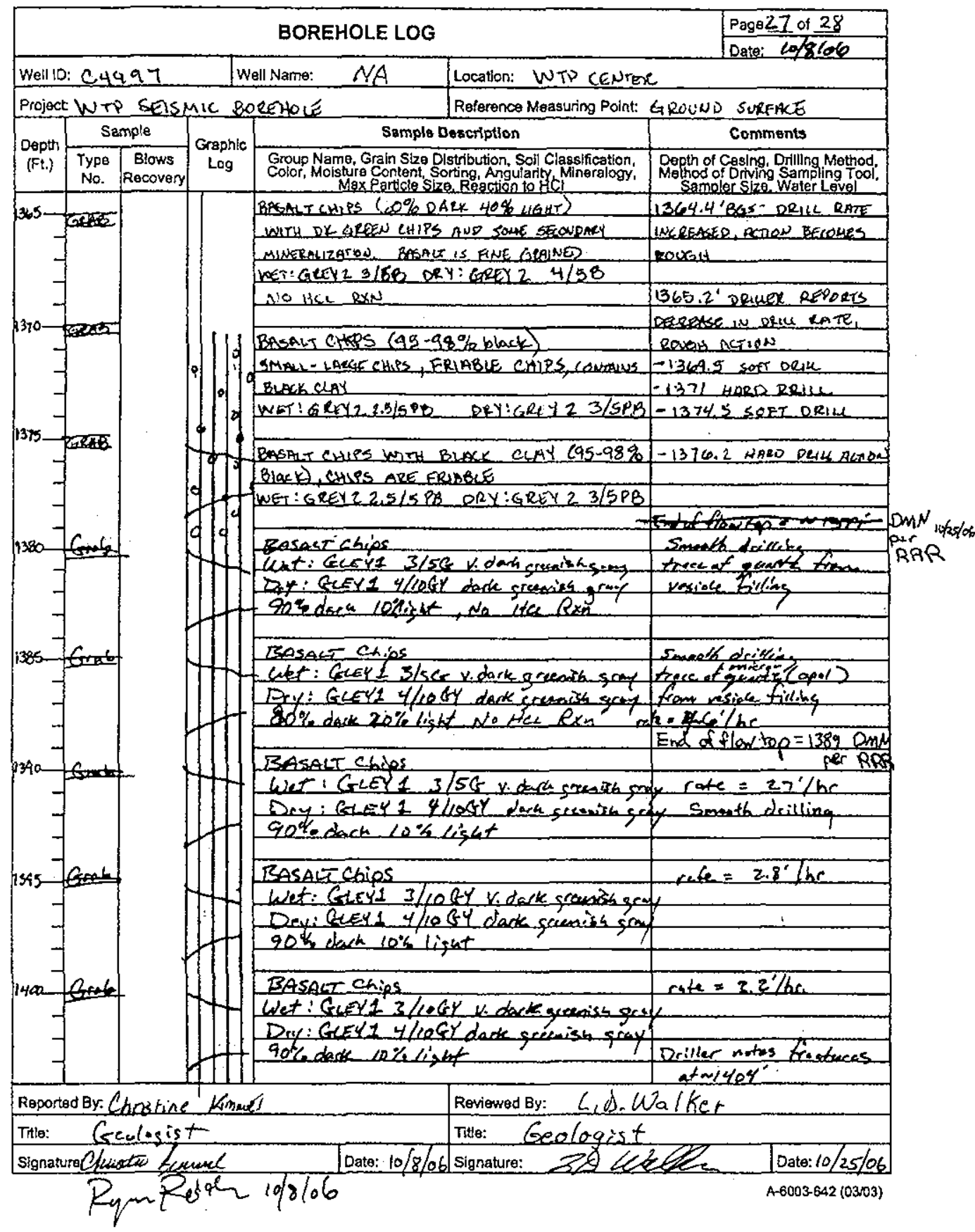


WMP-31815, Rev. 0

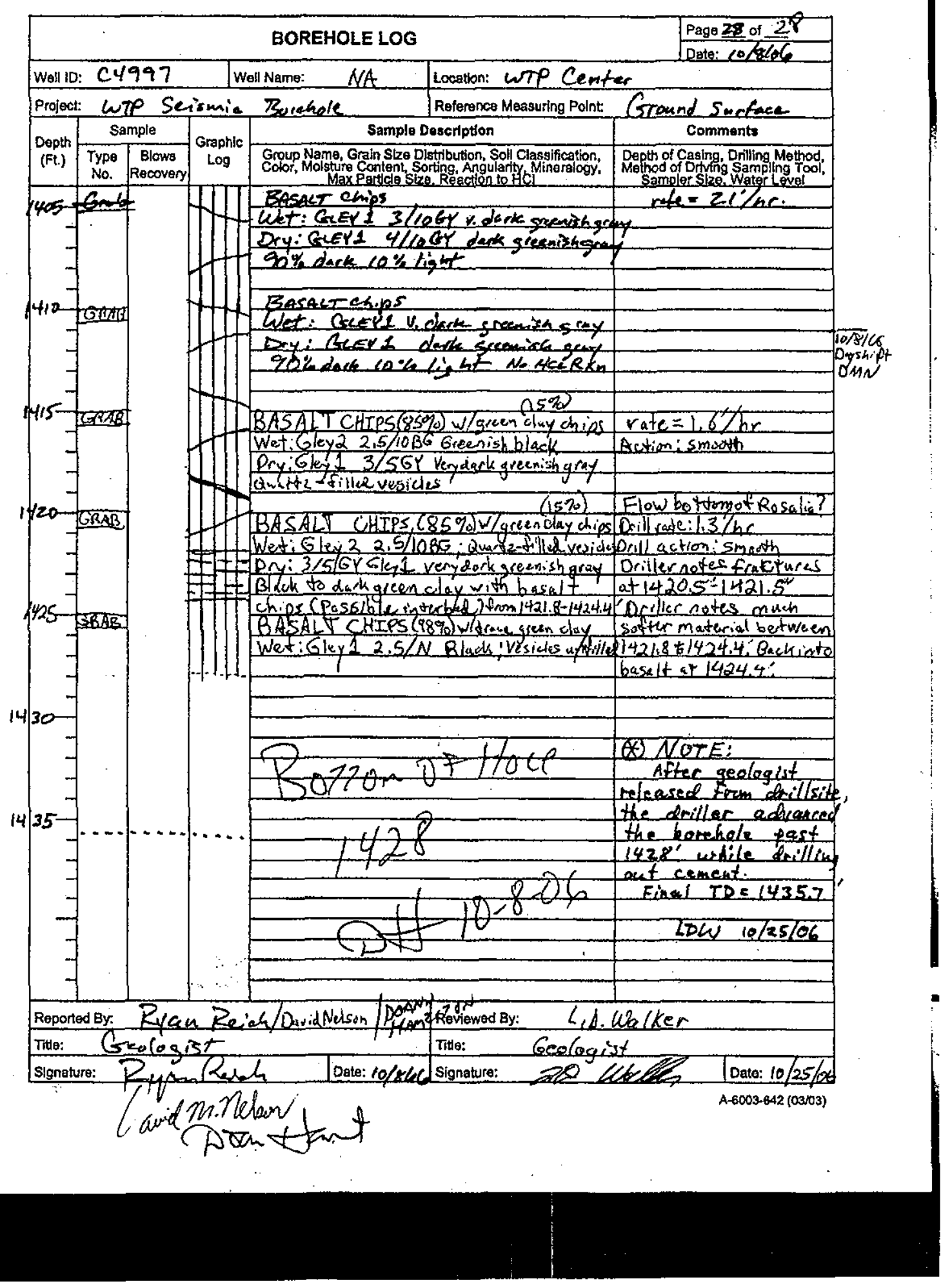


WMP-31815, Rev. 0

This page intentionally left blank. 
WMP-31815, Rev. 0

\section{APPENDIX B}

Photocopied Geological Borehole logs for Hanford and Ringold formations in borehole c4997 
WMP-31815, Rev. 0

This page intentionally left blank.

B-ii 


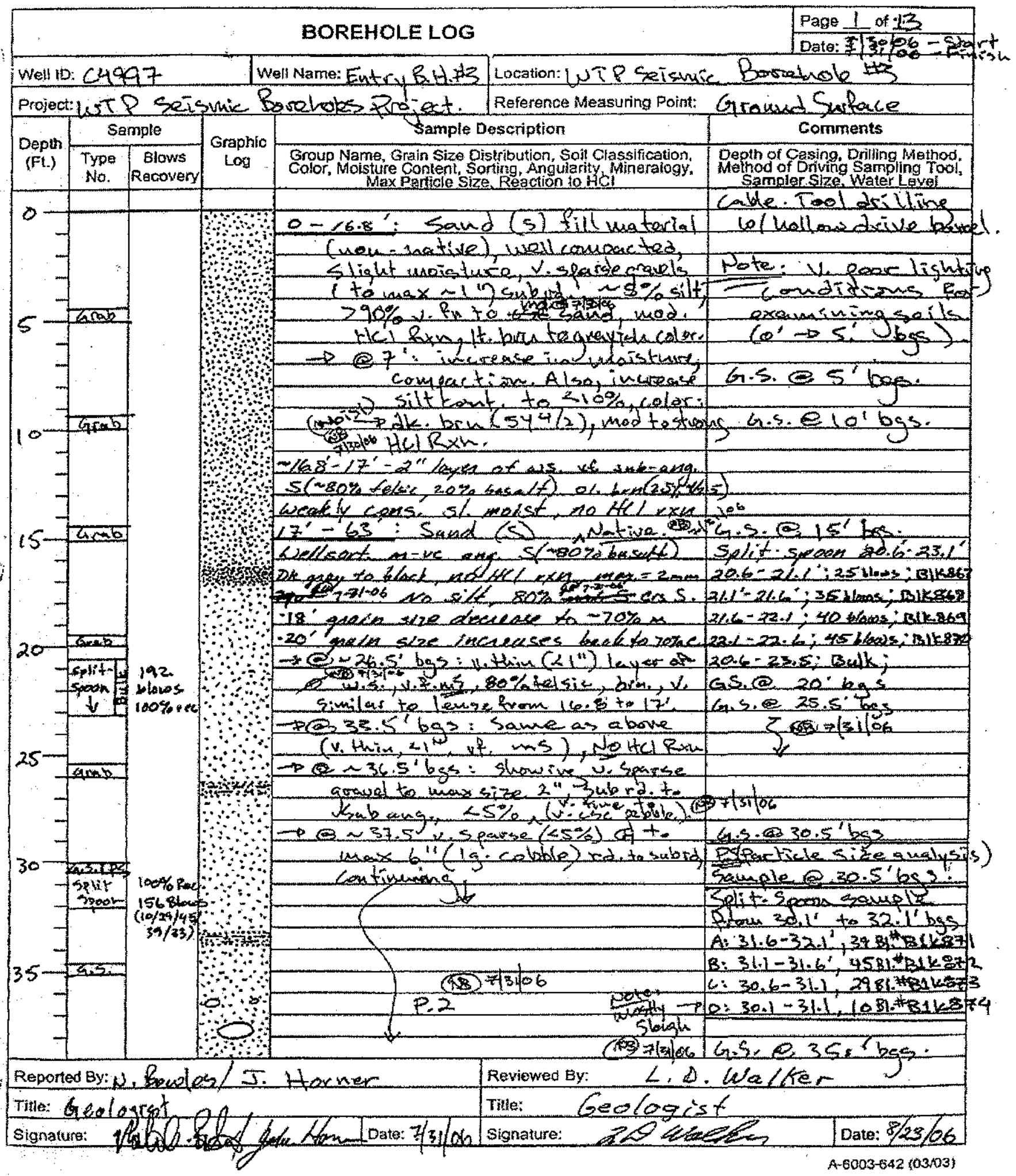




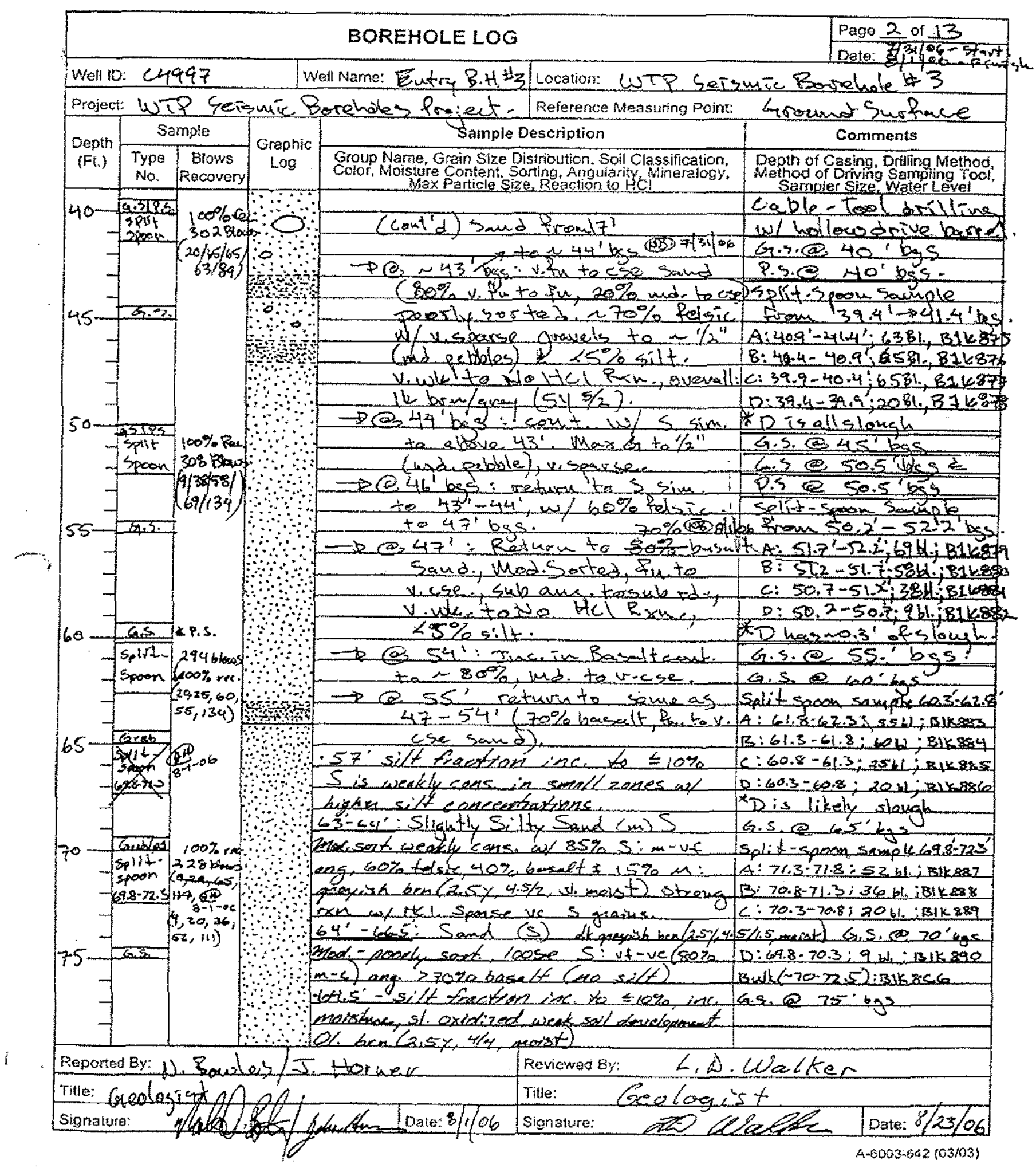




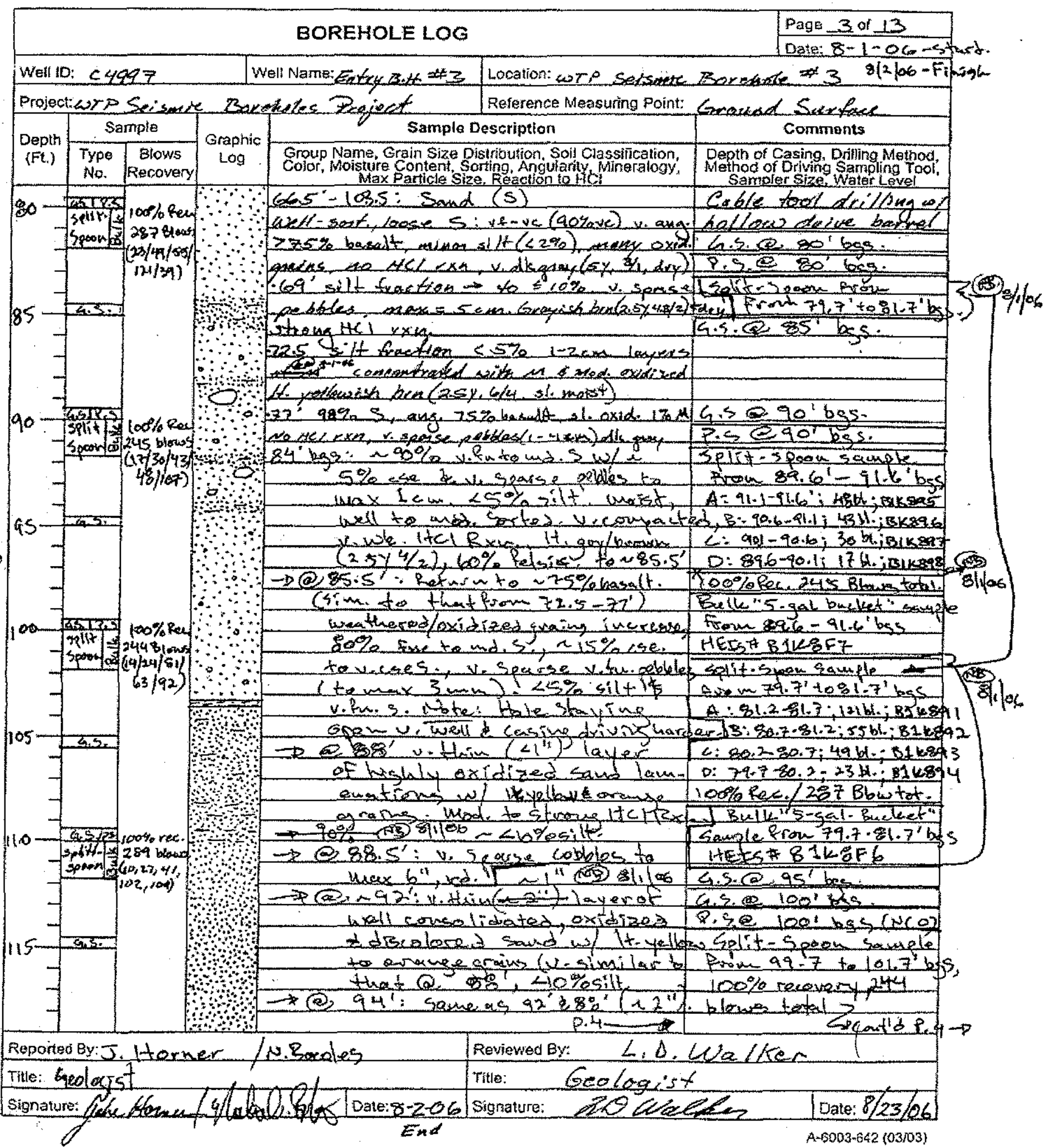




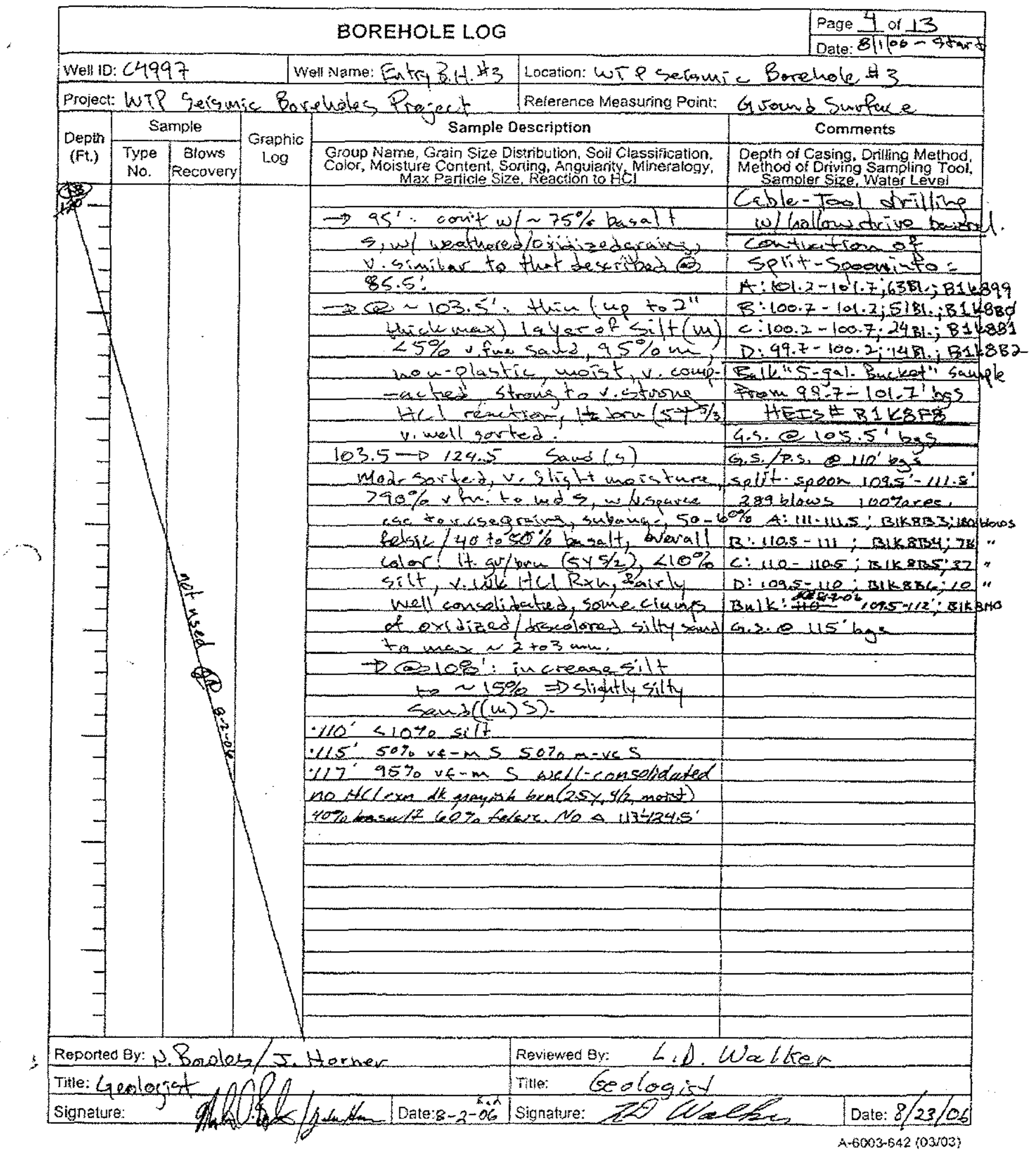




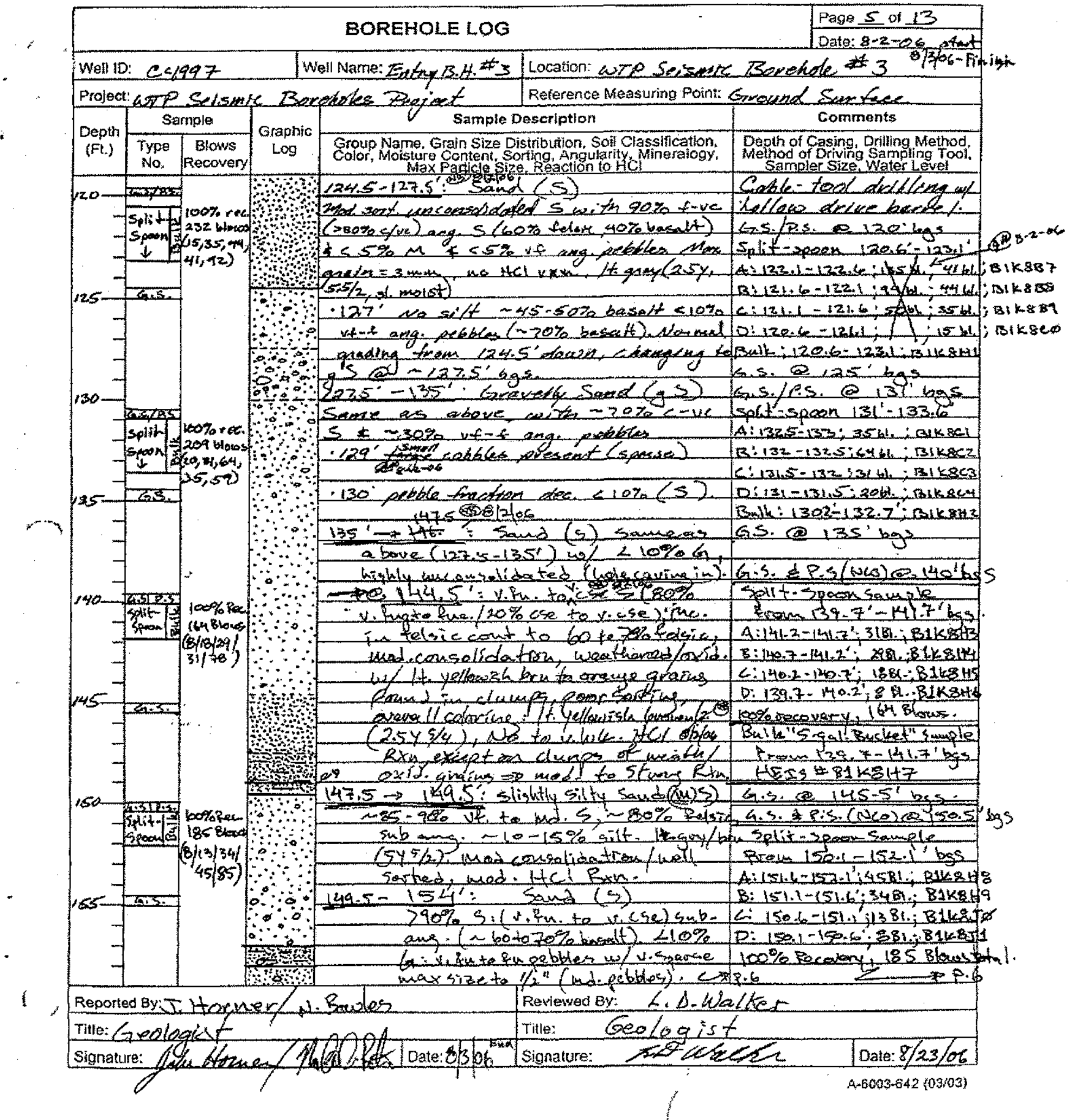




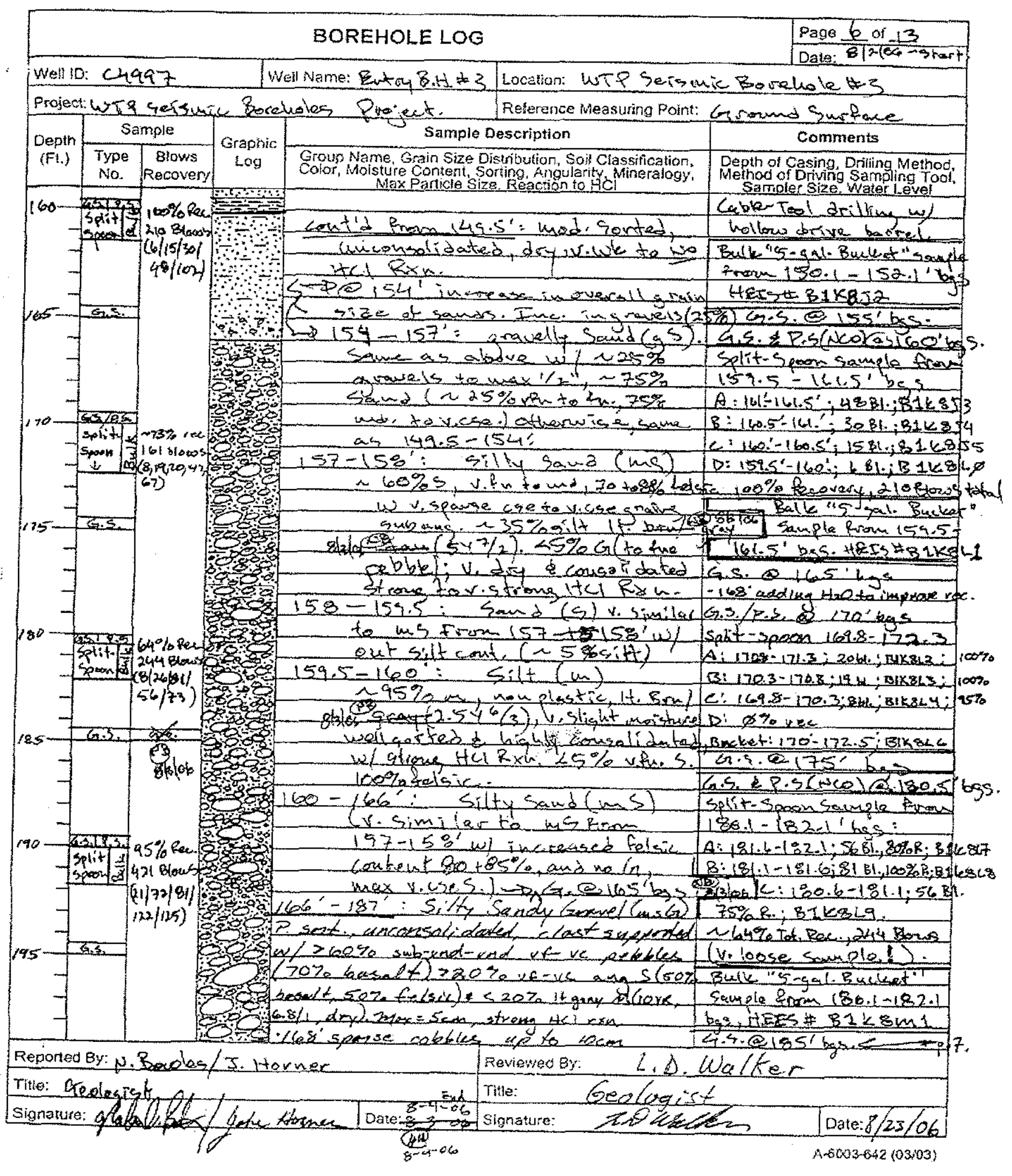




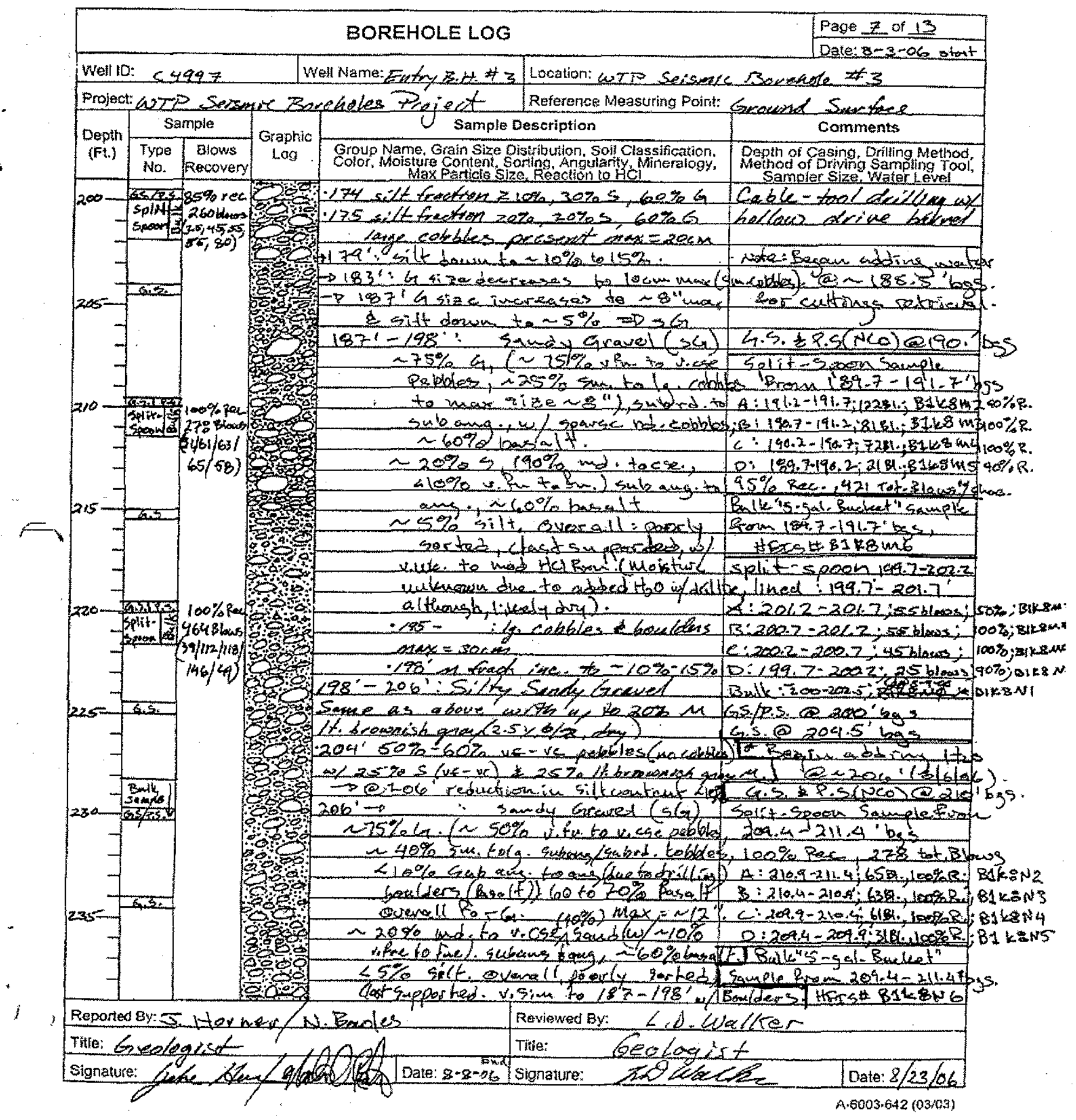




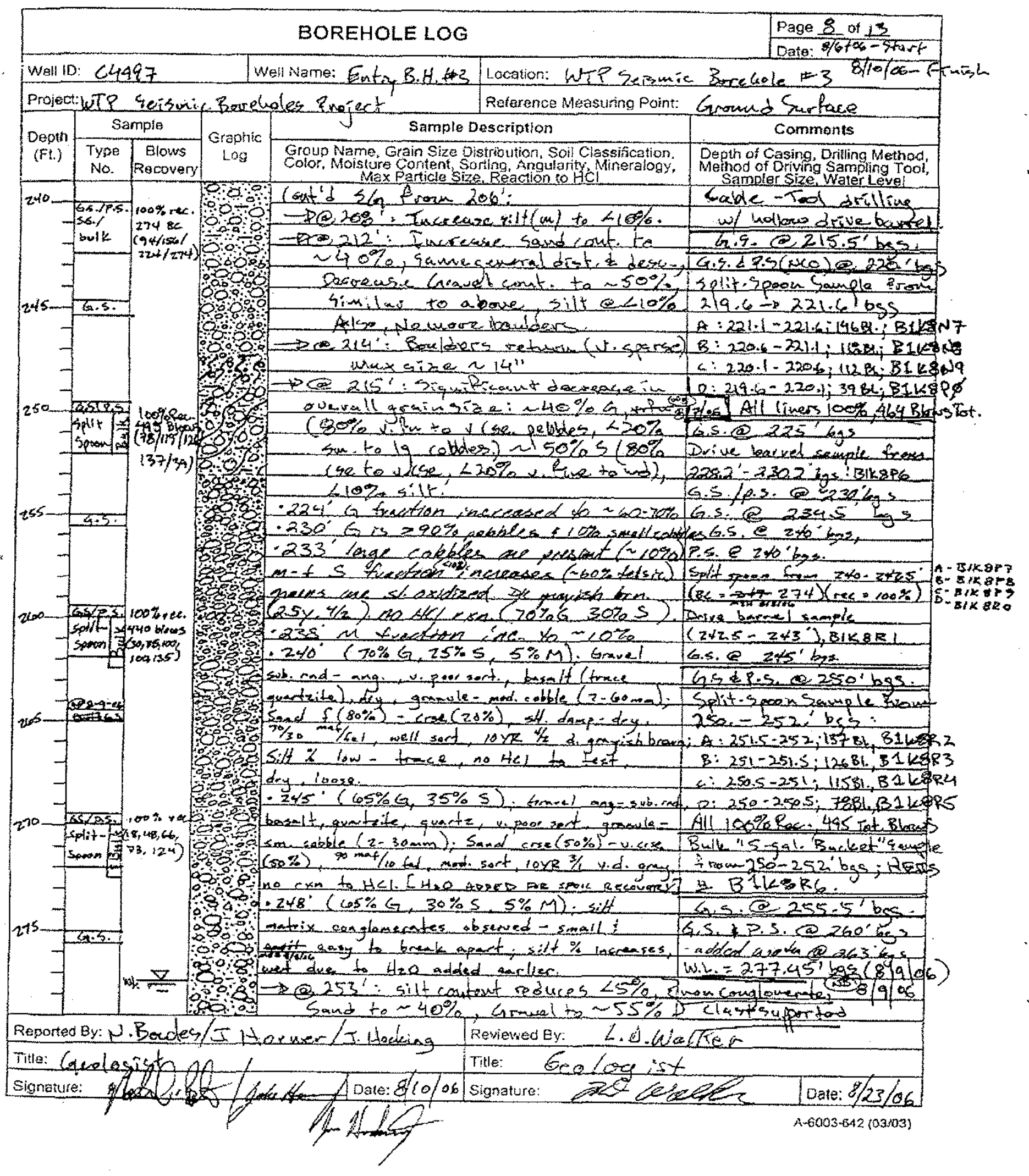


WMP-31815, Rev. 0

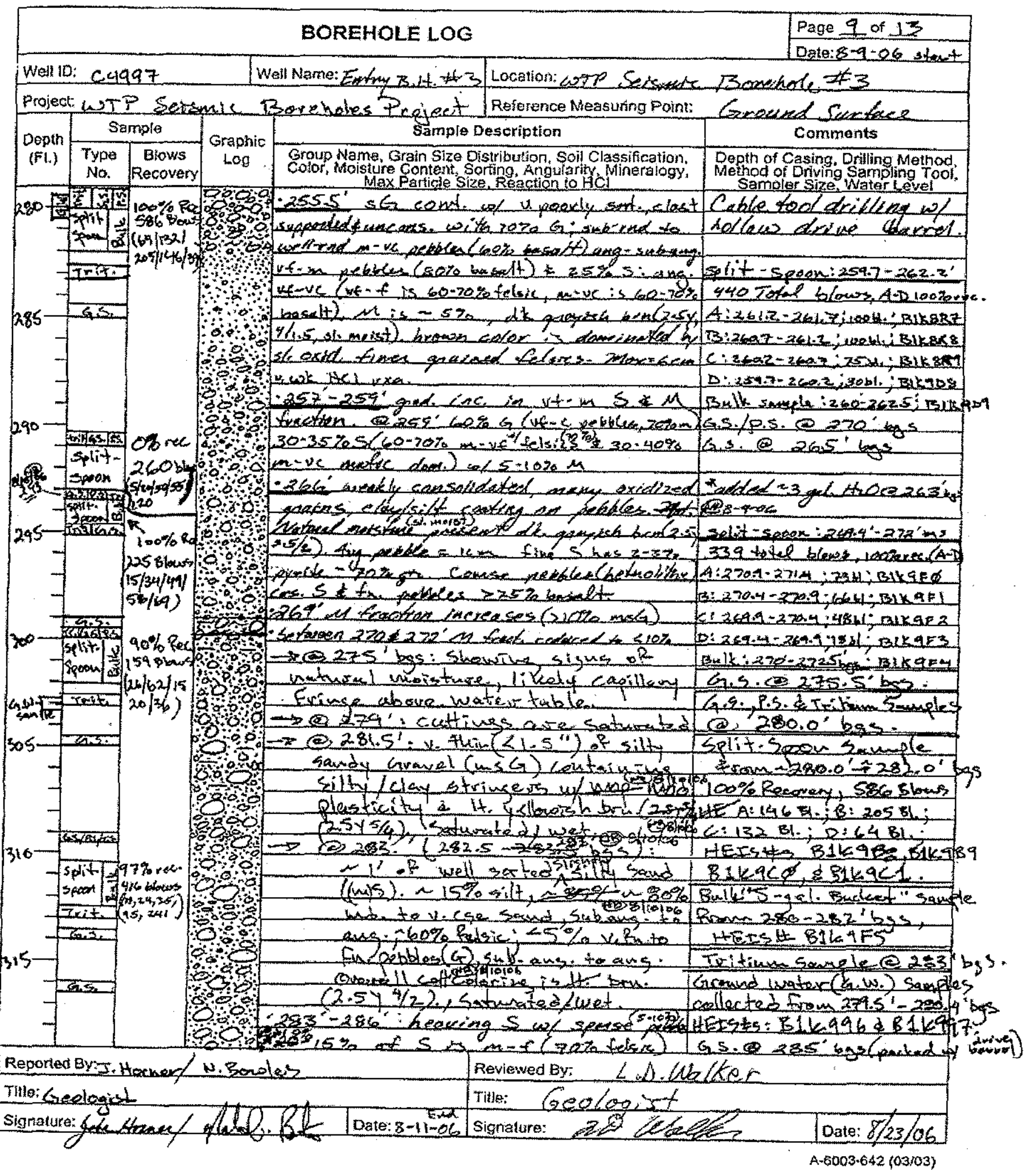




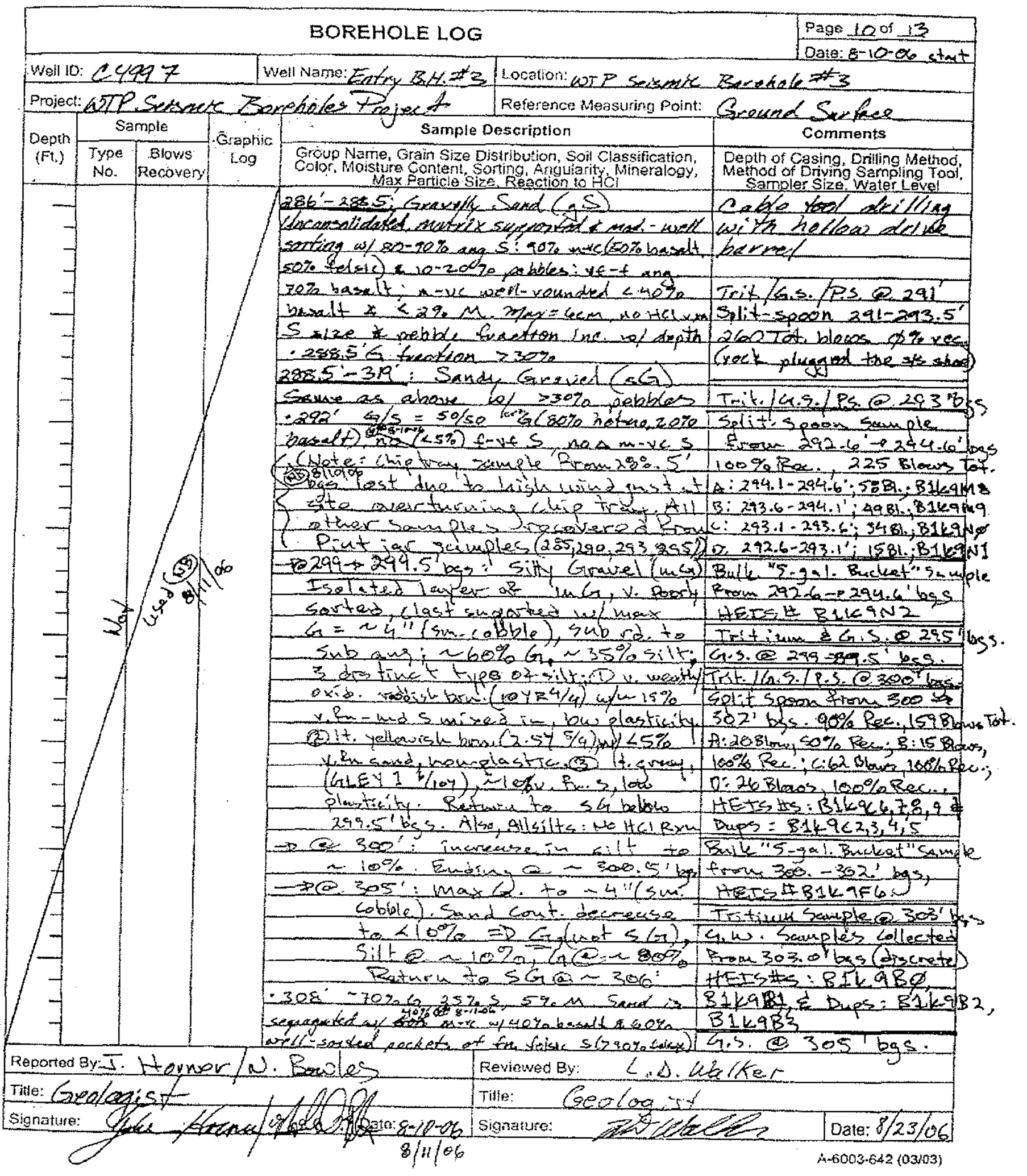




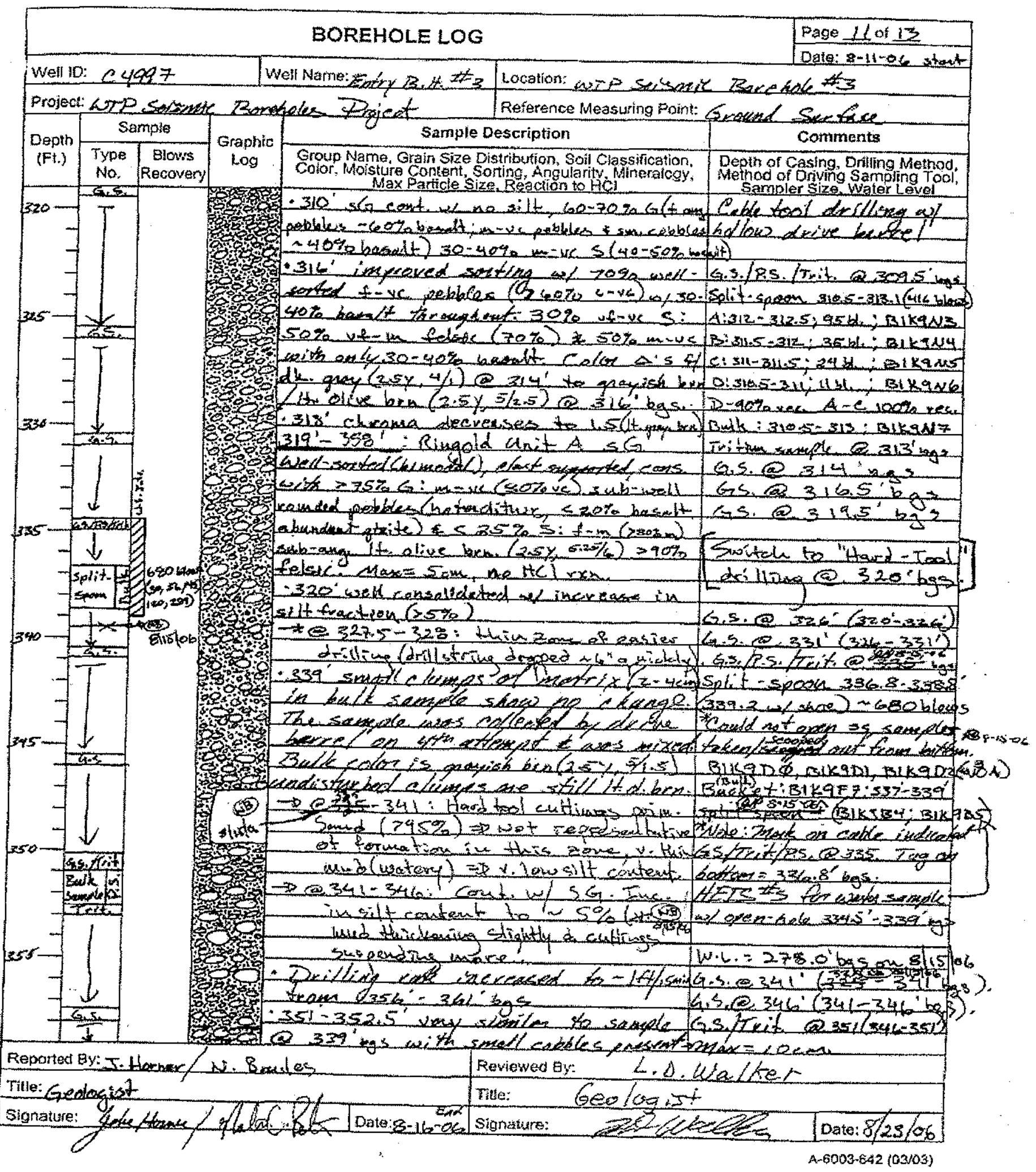




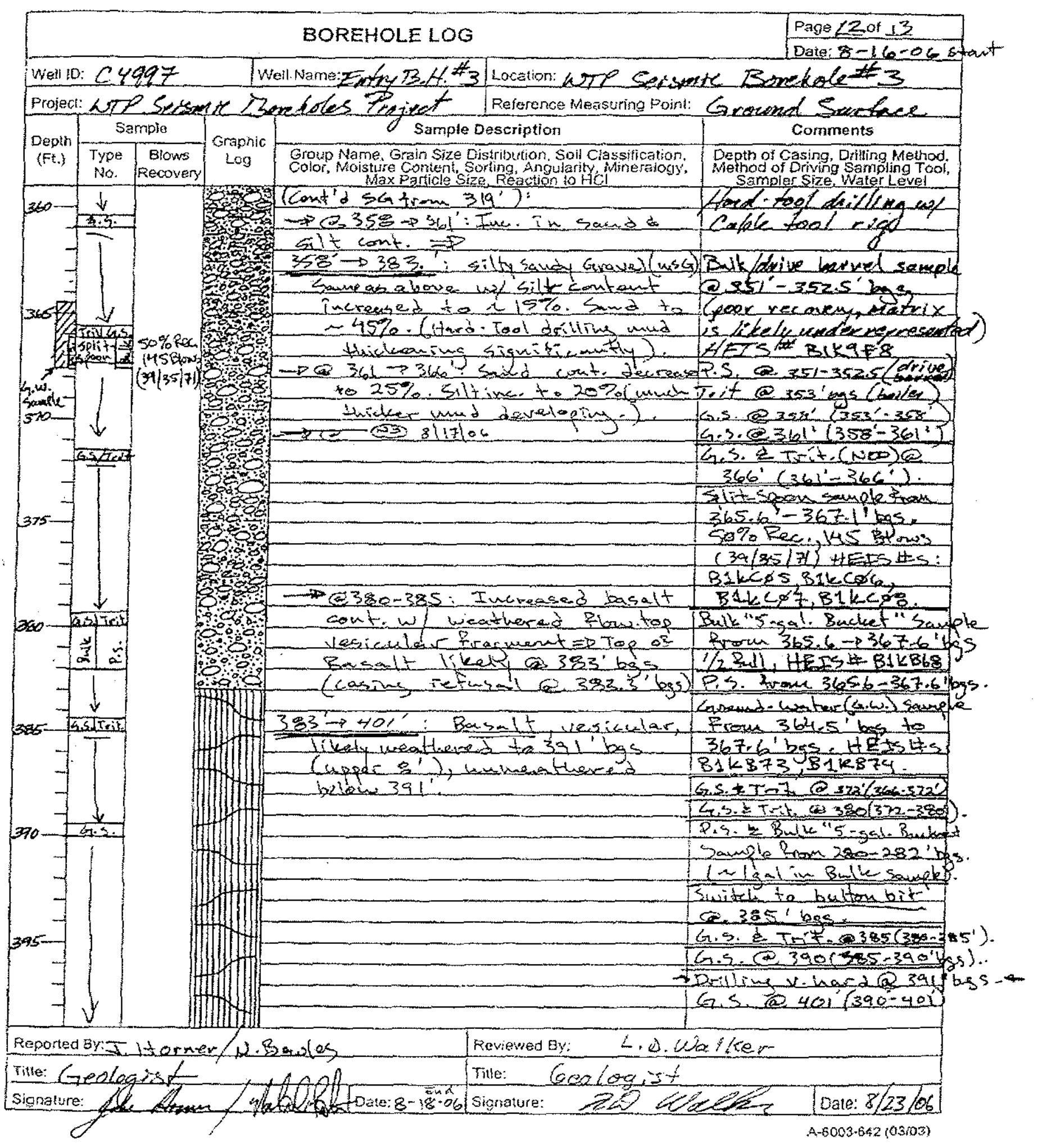


WMP-31815, Rev. 0

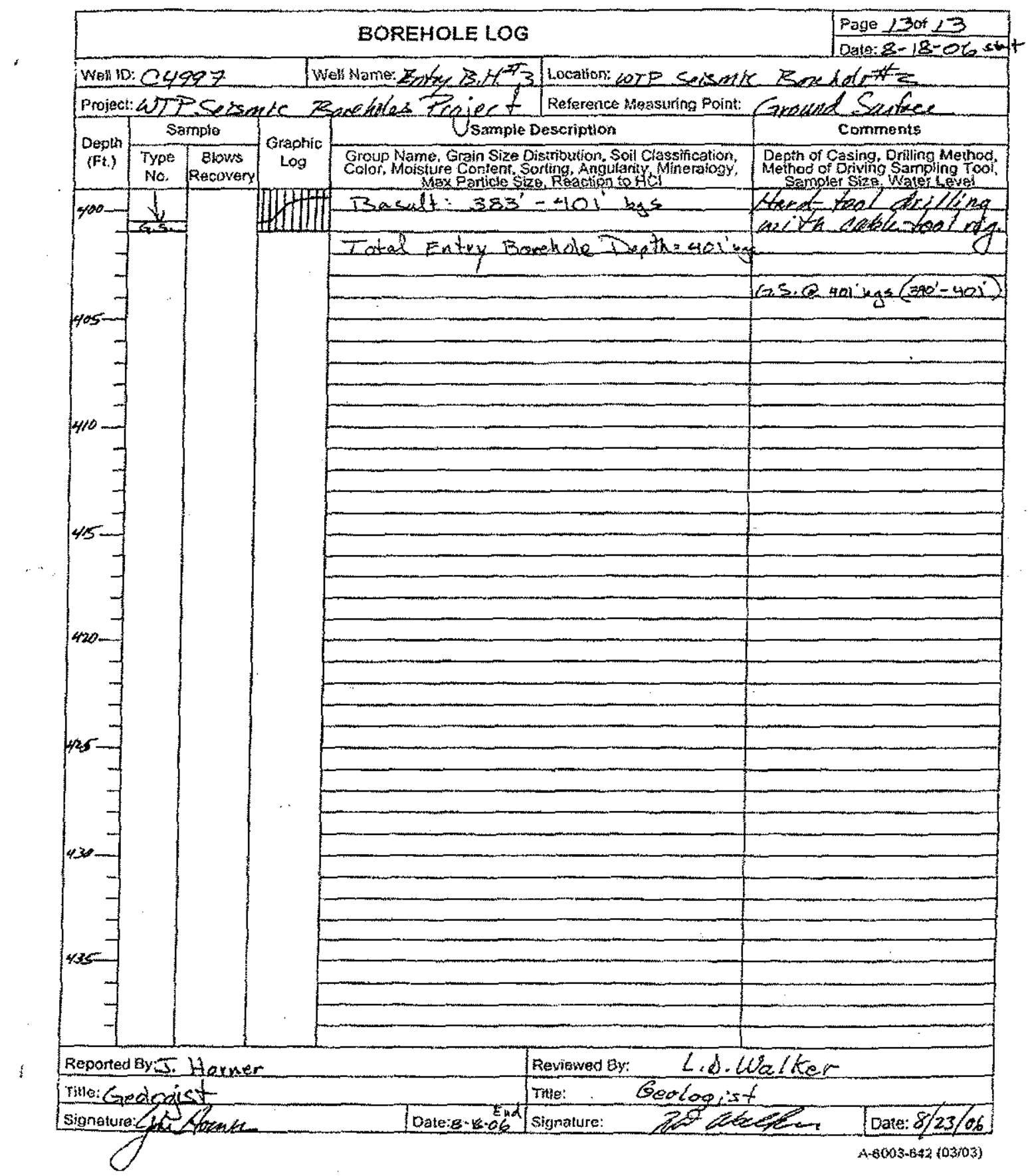


WMP-31815, Rev. 0

This page intentionally left blank. 


\section{DISTRIBUTION}

\section{Onsite}

Fluor Hanford, Inc.

J. V. Borghese

E6-35

G. D. Cummins

E6-35

D. B. Erb

E6-35

L. J. Farrell

(3)

L. C. Swanson

E6-35

J. A. Winterhalder

E6-35

L. D. Walker

E6-35

C. S. Wright

E6-35

2 Lockheed Martin Services, Inc.

Central Files

B1-07

Document Processing Center

H6-08

3 Pacific Northwest National Laboratory

Hanford Technical Library

P8-55

D. B. Barnett

K6-75

B. N. Bjornstad

K6-81

T. M. Brounds

K9-69

A. C. Rohay

K6-75

S. P. Reidel

K6-75 